\title{
The Organization of the Octavolateralis Area in Actinopterygian Fishes: A New Interpretation
}

\author{
CATHERINE A. McCORMICK \\ Division of Biological Sciences, the University of Michigan, Ann Arbor, \\ Michigan 48109
}

\begin{abstract}
The octavolateralis area of actinopterygian fishes can be subdivided into a dorsal lateralis area composed of first-order lateral line nuclei, and a ventral octavus area composed of nuclei receiving first-order input from the eighth nerve. Three patterns of organization of the lateralis area are recognized in the present study. The organization of this area in polypteriforms and chondrosteans is similar to that in chondrichthyans. On the basis of recent studies in chondrichthyans (McCready and Boord, 76; Boord and Campbell, 77; Bodznick and Northcutt, ' 80 ), it is hypothesized that this pattern reflects the subdivision of the lateral line system into mechanoreceptive and electroreceptive portions. As petromyzontid agnathans also share this pattern of organization, it is hypothesized that they are electroreceptive. The lateralis area of holosteans and nonelectroreceptive teleosts exhibits a second organizational pattern that is hypothesized to reflect the loss of the electroreceptive portion of the lateral line system; it is suggested that electroreception was lost sometime between the chondrostean and teleostean radiations. Each group of electroreceptive teleosts is believed to have evolved electroreception independently (Bullock, "74), a situation that is reflected centrally by a third organizational pattern within the lateralis area, which is distinctly different from that of early radiations of electroreceptive fishes.

The octavus area of actinopterygians exhibits two patterns of organiza. tion - that of polypteriforms, chondrosteans. and holosteans, and that of teleosts. The functional significance of these patterns has yet to be elucidated.
\end{abstract}

Since the classic anatomical studies of Pear. son ('36a,b), Larsell ('67), and others on the oc' tavolateralis (acousticolateralis) area of fishes, there has been a substantial increase in information concerning the sensory systems that have primary projections to this area, and traditional notions of the functional nature of these sensory systems-the otic endorgans and the lateral line system - are being reexamined. For example, whereas the labyrinth of most fishes was once thought to contain only vestibular endorgans, it is now known to serve an auditory function in chondrichthy ans and actinopterygians (e.g., see reviews by Popper and Fay, 77; Fay and Popper. '80). Furthermore, the importance of the mechanoreceptors of the lateral line (lateralis) system as auditory endorgans (as they are often classified) can be questioned on the basis of recent studies that, taken together, suggest that they may be responsive to a class of stimuli biologically dis- tinct from sound (Dijkgraaf, '63, '67; Schwartz, 67; Cahn, 72: Pitcher et al., '76; Partridge and Pitcher, '80; Sand, '81). In addition, the lateralis system of certain fishes can be considered to include the electroreceptors, a class of endorgans discovered only within the past 20 years (Lissman and Machin, '58; Bullock et al., '61), and thus not considered in much of the literature dealing with the anatomy and evolution of the octavolateralis area. Thus, as many as four classes of sensory endorgans can be grouped within the octavolateralis system: the auditory and vestibular endorgans of the laby. rinth, innervated by the octavus (eighth) nerve, and the mechanoreceptive lateralis endorgans and electroreceptors, innervated by various components of the anterior and posterior lateralis nerves in different taxa.

C A. McCormick's pregent address is Department of Anatomy. Georgetown University Schools of Mudicine and Dentislry, 3900 Reservoir Hd. NW. Washuzhon, DC 20ker? 
Recent investigations of the central projections of the eighth and lateralis nerves have defined the octavolateralis area of the medulla in a way that differs significantly from that set forth in classical, nonexperimental studies. With the exception of one teleost group, the mormyrids (Bell and Russell, '78; Bell, '81), the fibers of the lateralis and eighth nerves largely terminate in separate nuclei within the octavolateralis area in agnathan (Northcutt, '79a, '80), chondrichthyan (Boord and Campbell, '77; Boord and Roberts, '80; Northcutt, ' 80 ), and holostean (McCormick, '78, '81) species ('Table 1). On this basis, the octavolateralis area can be subdivided into a dorsal lateralis region and a ventral octavus region in at least these early radiations of fishes. In contrast, classical analyses considered these nerves to overlap extensively in their first-order termination sites in a wide variety of species and did not consider the nuclear organization of the octavolateralis area to be as complex as is currently believed.

A review of the nonexperimental literature concerning the octavolateralis area reveals conflicting views concerning its subdivisions and evolution (e.g., Pearson, '36a,b; Larsell, 67; Maler, '74). In contrast, the majority of recent studies in chondrichthyans and actinopterygians largely concur in their descriptions and nomenclature of the nuclei that comprise the octavolateralis area (Table 1). Although these studies involve a smail sampling of species, the fact that the cartilaginous and rayfinned fishes possess many common organizational features within the octavolateralis area strongly suggests that these features characterize the octavolateralis area in these radiations and may thus constitute a legitimate framework on which to base a comparative study of the octavolateralis nuclei among fishes. In addition, the demonstration that in at least some species the mechanoreceptive and electroreceptive portions of the lateralis system are centrally segregated has greatly facilitated comparisons of the lateralis nuclei among different species. Because previous studies of the organization and evolution of the octavolateralis area preceded experimental analyses of this area, a reinterpretation of the evolution of this area is clearly warranted. The present study reviews the organization of the octavolateralis area in selected species of actinopterygian fish in light of these recent studies, and provides a new hypothesis concerning the evolution of this area.

\section{MATERIALS}

The octavolateralis area was studied in the species listed in Table 2, using cresyl violet- or
Bodian-stained material sectioned in the transverse plane. 'The author thanks Dr. R. Glenn Northcutt for providing much of this material from his collection. The species listed in Table 2 include representatives of all four actinopterygian groups (Romer, '66: Schaeffer, '73; Gardner, '73).'

\section{METHODS}

The pattern of organization of the octavolateralis area in the holostean, Amia calva, which was described previously (McCormick, 78,81 , provided the basic framework against which the octavolateralis area in other actinopterygians was compared. Amia is suitable for this purpose for two reasons. First, the octavolateralis area in Amia likely retains many generalized, or primitive, features, as recent studies in chondrichthyans indicate that the octavolateralis area in these fish is similar to that of Amia I'Table 1). In addition, Amia is one of two actinopterygian groups for which the first order projections of both the octavus and lateralis nerves are known and, unlike species of the other group, the mormyrids, (Beil and Russell, '78; Bell, '81) Amia retains the apparently primitive characteristic of separate octavus and lateralis subdivisions within the octavolateralis area (McCormick, ' 81 ). It is thus convenient at this point to describe briefly the octavolateralis nuclei in Amia. A more complete account is found elsewhere (McCormick, '78, '81).

\section{The pattern in Amia}

The octavolateralis area in Amia can be divided into a dorsal and a ventral longitudinal cell column (Fig. 1). The dorsal column consists of two nuclei that receive first-order input from the lateral line mechanoreceptors, nucleus medialis and nucleus caudalis. ${ }^{2}$ Nucleus medialis (Fig. 1B,C,D) forms the major portion of the dorsal, lateralis column and lies im-

\footnotetext{
'The taxonomic nomenclature employed in the text and tables of this report largely follows that used in many of the studies of the octavolateralis area reviewed in this manu. script. with the exception that the Polypteriformes were fre. quently classified together with the Chondrostei. Other inlerpretations of the texonomic relationships among sctin. optery gians have been proposed, e.g. Wiley (79) and Liem and Lauder (in press).
}

'I ateral line electroreceptors were not believed to be present in Amic at the time of this study, and a recent electrophysiological report has confirmed that $A$ mia is not elec. troreceptive (Northcutl et al., '80). 


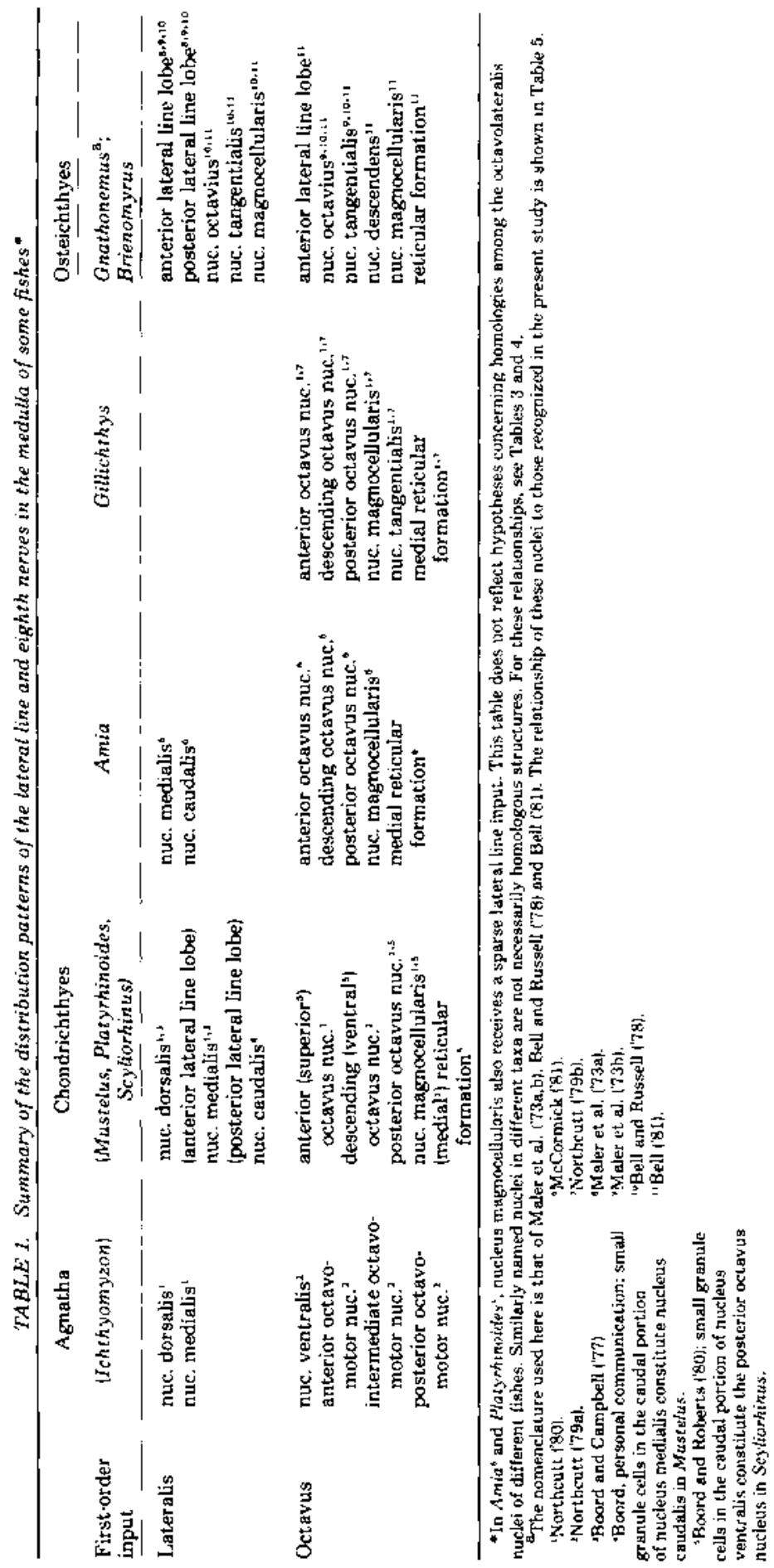


TABLE 2. Species of fish used in this investigation

\begin{tabular}{|c|}
\hline 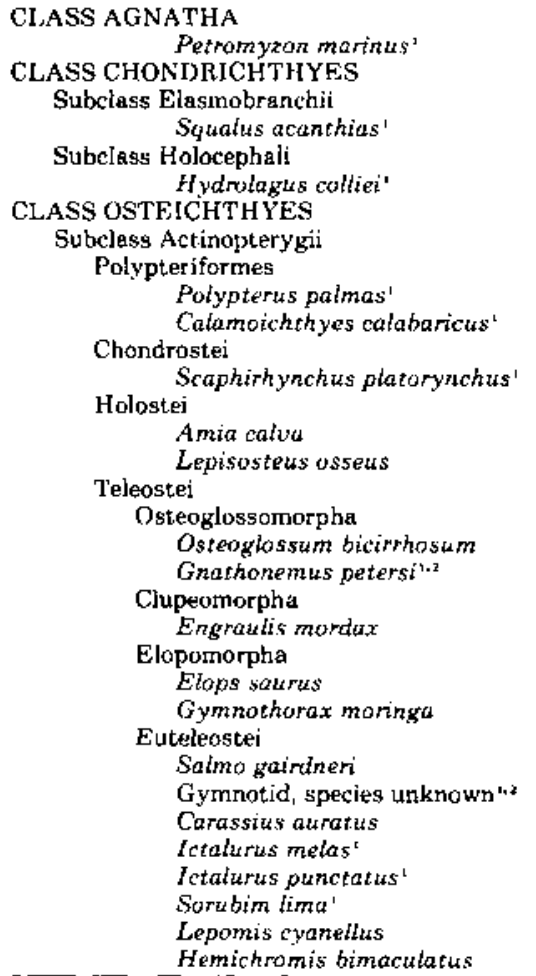 \\
\hline
\end{tabular}

'Species is known or sugpected to be electroreceptive. ispecies possesses an electric organ.

mediately ventral to the cerebellar crest-a caudal extension of the molecular layer of the cerebellum. Nucleus medialis consists of a dorsal region of large, Purkinje-like cells and a ventral region of fusiform, poiygonal, and granule celis. Nucleus caudalis (Fig. 1A) replaces nucleus medialis posteriorly. It is situated on the dorsolateral aspect of the medulla and contains only smal] [5 $\mu \mathrm{m}$ in diameter) spherical cells.

The ventral cell column of the octavolateralis area contains four first-order octavus leighth nerve) nuclei. The anterior octavus nucleus (Fig. 1D) is situated rostral to the entering eighth nerve rami and consists of fusiform cells. Nucleus magnocellularis (Fig. 1C) is found at the level of entrance of the eighth nerve and contains large, multipolar cells that stain darkly with cresyl violet. The descending octavus nucleus (Fig. 1B), a cluster of fusiform cells, replaces nucleus magnocellularis caudal. ly and is itself replaced by the posterior octavus nucleus. The posterior octavus nucleus (Fig. 1A) contains small, loosely packed spherical cells $(5 \mu \mathrm{m}$ in diameter) and is situated ventral to the more compact nucleus caudalis.

\section{RESULTS}

\section{Organization of the lateralis cell column in actinopterygians}

In the species studied, the lateralis region consists of either a single longitudinal column of cells, as in Amia, or is partitioned into a pair of longitudinal columns in one of two ways, as summarized in Figure 2. Three patterns of organization are thus seen in the lateralis area. The lateralis area of two early actinopterygian radiations (the Polypteriformes and the Chondrostei) - as well as that of two other vertebrate classes (the Agnatha and the Chondrichthyes) displays one of these patterns (Fig, 2A). The second organizational pattern is found in the Holostei and among nonelectroreceptive members of the Teleostei (Fig. 2B). The electroreceptive teleosts exhibit the third organizational pattern (Fig. 2C).

The lateralis area in polypteriforms and chondrosteans

The organization of the lateralis area in polypteriforms and chondrosteans is distinctly different from that of later radiations of the ray-finned fishes (Figs. 2, 3). In contrast to the single cell column of $A$ mia (Fig. 1), the lateralis nuclei in polypteriforms (Figs. 3d, 4) and chondrosteans (Figs. 3e, 5) form two longitudinal cell columns. One of these columns consists of a prominent nucleus medialis and a small nucleus caudalis. This column is therefore similar to the single lateralis cell column that has been experimentally defined in Amia. The other lateralis cell column in polypteriforms and chondrosteans lies medial or dorsomedial to the first column and consists of one nucleus, nucleus dorsalis. Nucleus dorsalis is not present in holosteans or teleosts.

Nucleus dorsalis is found rostromedially within the octavolateralis area. In Polypterus and Calamoichthys, nucleus dorsalis is situated largely medial to nucleus medialis and ventral to the cerebellar crest, although some of its cells are located on the dorsal surface of the cerebellar crest. In these fish, the cerebellar crest associated with nucleus dorsalis is separated from the crest overlying nucleus medialis by a fiber tract composed at least partially of axons of the dorsal ramus of the anterior lateral line nerve. The position of the chondrostean nucleus dorsalis in relation to nucleus medialis differs from that in polyp- 

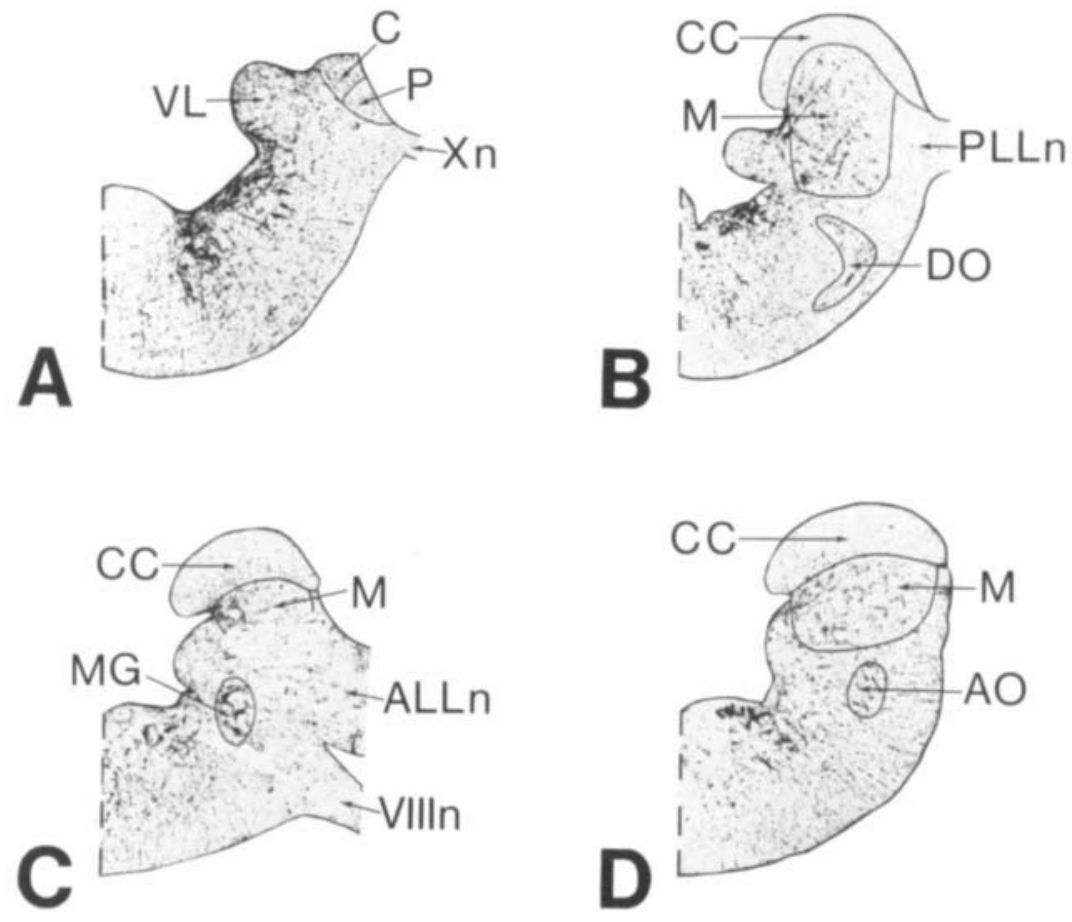

Fig. 1. Photomicrographs of tranverse sections through the octavolater alis area of Amia calva: A is the caudalmost section. Cresyl violet. Abbreviations: ALLn, anterior lateral line nerve: $\mathrm{AO}$. anterior octavus nucieus; $\mathrm{C}$, nucleus caudalis; $\mathrm{CC}$. cerebellar crest; 1)O. descending octavus nucleus; $M$, nucleus medialis; MG, nucleus magnoceliularis; PLIn. posterior lateral line nerve: $\mathrm{P}$, posterior octavus nucleus; VIIIn, eighth nerve; VI, vagel lohe; $\mathrm{Xn}$, vagus nerve.

teriforms because of the eversion of the dorsomedial portion of the cerebellum in the former group (Larsell. '67). This results in nucleus dorsalis overlying its cerebellar crest (Figs.3e,5B,C,D). Like nucleus medialis, nucleus dorsalis contains Purkinje-like, fusiform and granule cells.

The presence of two longitudinal lateralis cell columns in polypteriforms and chondrosteans is associated with the division of the anterior lateral line nerve into dorsal and ventral rami, a condition not generally found in later radiations of fishes. In studies of normal material the dorsal ramus of the anterior lateralis nerve was traced to nucleus dorsalis and the ventral ramus of this nerve and the posterior lateralis nerve to nucleus medialis (Johnston, '01; van der Horst, '25; Larsell, '67). Although eighth nerve input to nucleus medialis was usually described in these nonexperimental studies, recent studies in other fishes by and large do not confirm this projection (Table 1: see Discussion).

There are no experimental anatomical data on the connections of the lateratis column in polypteriforms or chondrosteans. However, the organization of the lateralis area in these fish is virtually identical to that of chondrichthyans (Fig. 3b,cl, and similar to that of one group of agnathans, the petromyzontids (Fig. 3a). The experimental data available for the two latter groups suggest a functional basis for the presence of two lateralis cell columns in the early radiations of actinopterygian fishes, and will be described in Discussion.

The lateralis area in holosteans and nonelectroreceptive teleosts

The lateralis area in the extant genera of holosteans and in teleosts known or believed to be nonelectroreceptive consists of a single longitudinal cell column containing nucleus medialis rostrally and nucleus caudalis posteriorly (Figs. 2B, 3f,h,i,j,k, 6). The cytoarchitecture and organization of this column in the species studied is similar or identical to that of Amia. In Amia, nucleus medialis and nucleus caudalis receive the vast majority of lateralis afferents to the medulla, with a small contingent of these fibers terminating in an octavus nucleus (nucleus magnocellularis\} (McCormick. '78, '81). Anatomical studies in nonelec. 

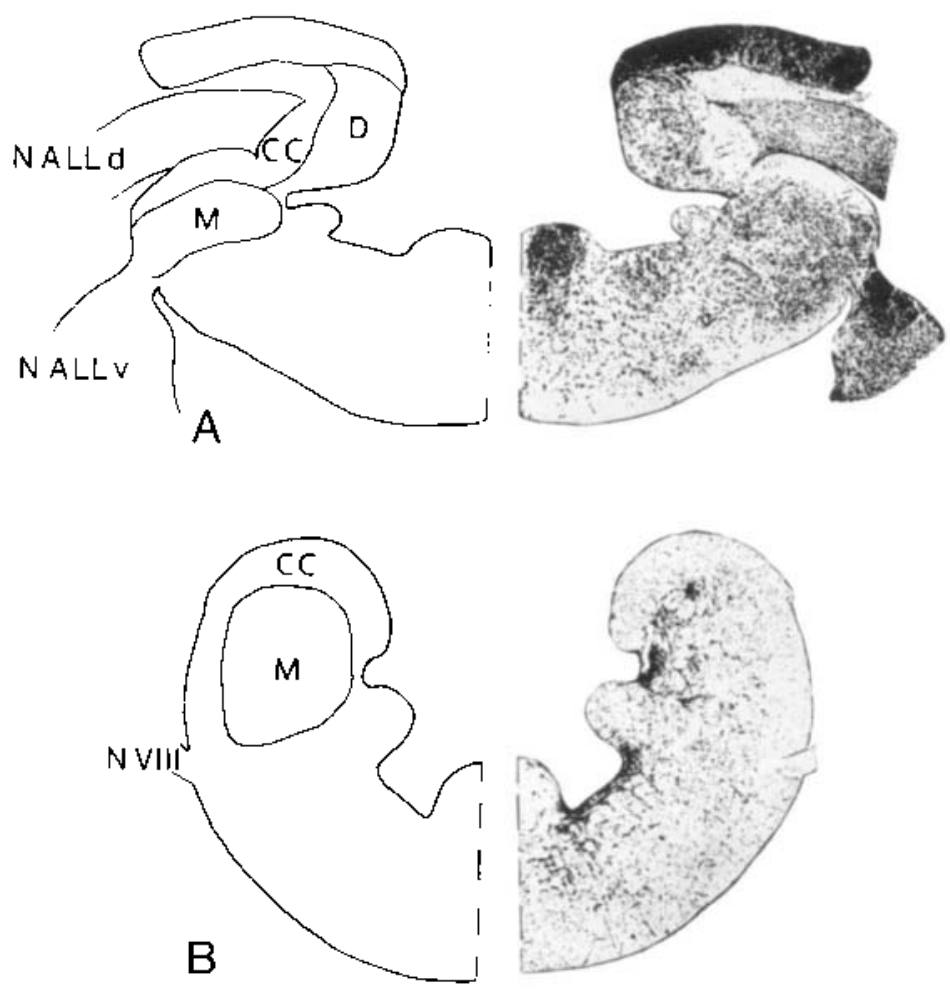

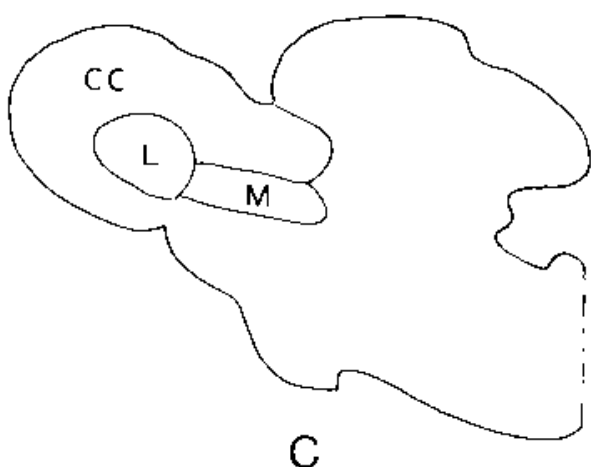

Fig. 2. A-C [llustration of the three organizational pat terns within the lateralis area of fishes. A. This pattern is characterized by two longitudinal lateralis columns, represented at this level by nucleus medialis and nucleus dorsalis. Nucleus dorsalis comprises the medial later alis col umn and is innervated by the dorsal ramus of the anterior lateral line nerve. This pattern is illustrated with a transverse section through the medula of chondrichthyan, Squalus acanthias, and is also present in petromyzontids, polypteriforms, and chondrosteans. B. This pattern is characterized by a single lateralis column, represented at this level by nucleus medialis; nucleus dorsalis is not pre sent. This pattern is illustrated with a transverse section

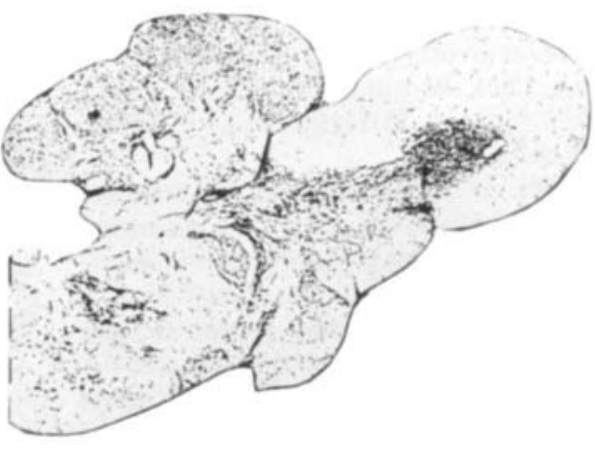

through the medula of a holostenn, Amia calua, and is also present in nonelectroreceptive teleosts. C. This pattern is characterized by two longitudinal lateralis columns. represented at this level by nucleus medialis and the lateral line lobe. The lateral line lobe comprises the lateral or dorsolateral lateralis column. This pattern is characteristic of electroreceptive teleosts and is illustrated with a transverse section through the medulla of Ictalurus punctatus. Abbreviations: $\mathrm{CC}_{1}$ cerebellar crest: $\mathrm{D}$, nucleus dorsalis: $\mathrm{L}$. lateral line lobe: $M$, nucleus medialis; N ALLd, dorsal ramus of the anterior lateral line nerve: N ALLv, ventral ramus of the anterior lateral line nerve; N VIII, eighth nerve. 

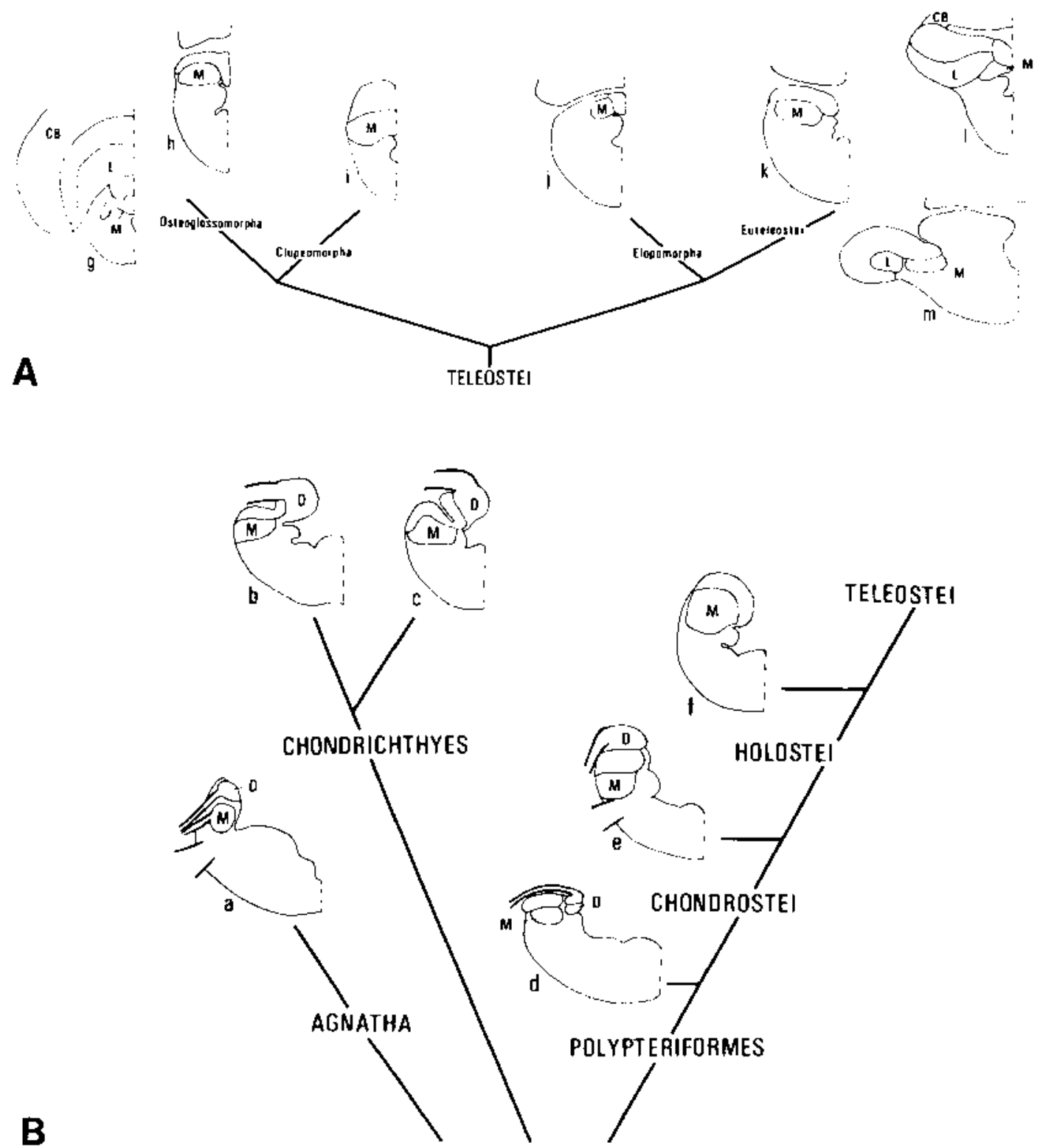

B

Fig. 3. Variations within the lateralis area of fishes. The interrelationships among the teleost groups follows that of Greenwood ('73). The pattern of organization represented in Figure 2A is shown here in the petromyzontid Petromyzon marinus fal; the elasmobranch Squalus acanthias (b): the holocephalan fHydrolagus collei (cl) the polypteriform Polypterus paimas (d); and the chondrostean Scaphirhyn. chus platorynchus (e). The most dorsul nerve in a-e is the dorsal ramus of the anterior lateral line nerve, entering nucleus dorsalis. The pattern of organization represented in

Figure $2 B$ is shown here in the holostean Amia calva (f); the osteoglossomorph Osteoglossum bicirrhosum (b): the clupeomorph Engraulis mordax (i): the elopomorph (jymnothorax moringa (j): and the euteleost Salmo gairdneri (k). The pattern of organization represented in Figure $2 \mathrm{C}$ is shown bere in the osteoglossomorph Gnathonemus petersi |gl; a gymnotid, species unknown $(\mathrm{l})$; and the euteleost Ictalurus punctatus (m). Abbreviations: CB, cerebellum; D. nucleus dorsalis; $\mathrm{I}$, lateral line lobe; $M$, nucleus medialis. 
|

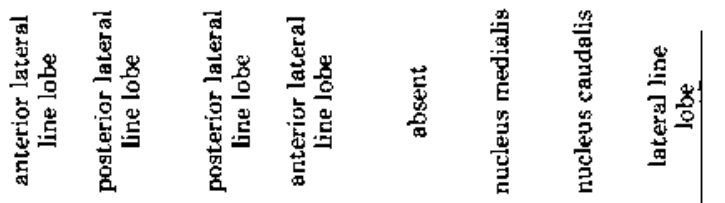

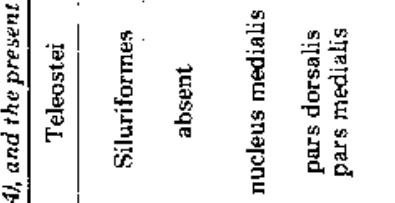

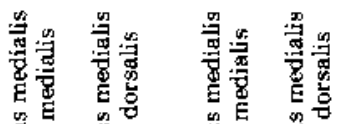

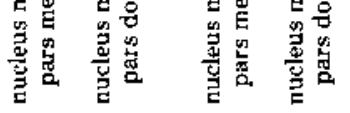

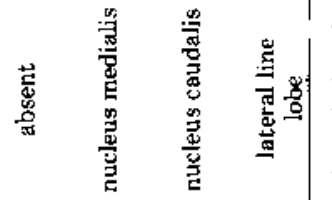

|

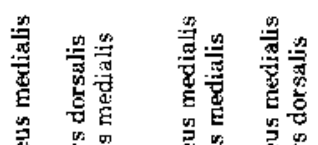

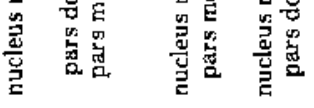

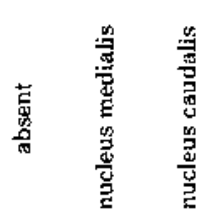
若

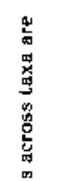

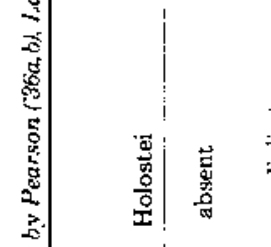

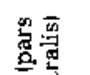

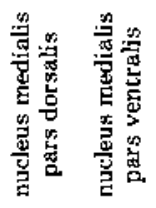

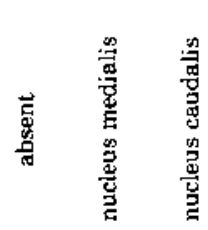

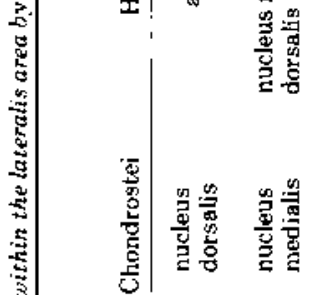

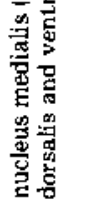

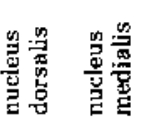

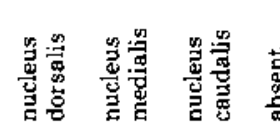
莺

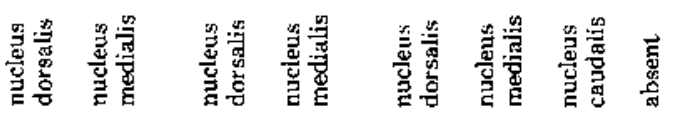

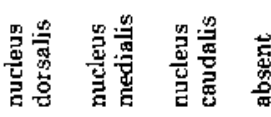

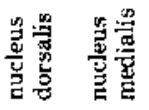

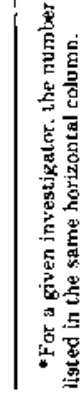



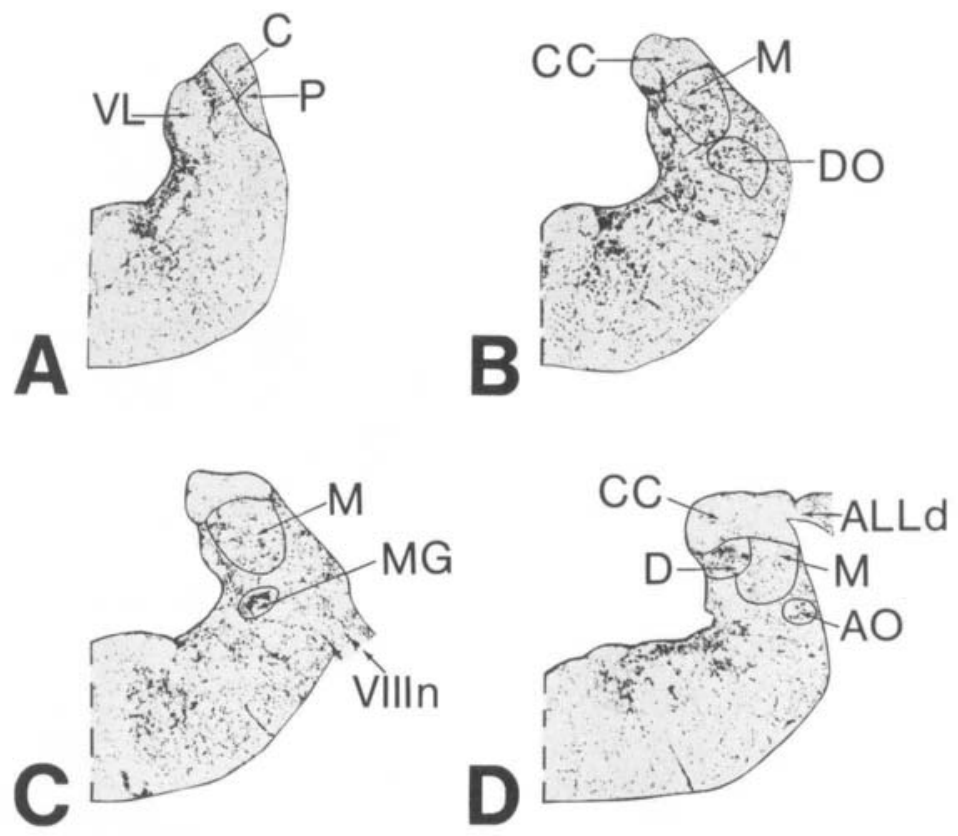

Fig. 4. Photomicrographs of transverse sections through the octavolateralis area of Calamoichthys calabaricus; A is the caudalmost section. Cresyl violet. Abbreviations: ALI_d, dorsal ramus of the anterior lateral line nerve; AO. anterior oct avus nucleus; $C$, nucleus caudalis; CC, cerebellar crest; D, nucleus dorsalis; DO, descending octavus nucleus; M, nucleus medialis: MG, nucleus magnocellularis: $P$, posterior octavus nucleus; VIIIn, eighth nerve, VL, vagal lobe.

troreceptive teleosts suggest that the pattern of lateralis input to the lateralis cell column is similar to that in Amia (Luiten, '75; personal observations). Pearson ('36a) subdivided a portion of the nucleus medialis in Carassius into a pars dorsalis and a pars medialis, and considered these subdivisions to be similar to those he observed in the nucleus medialis of silurids (an electroreceptive farnily). He also recognized dorsal and ventral subdivisions within the rostral portion of nucleus medialis in Amia. However, neither the cytoarchitecture (Amia, Carassius) nor the afferent lateralis input (Amia) to nucleus medialis supports such subdivisions, and they are not recognized in the present study.

The lateralis area in electroreceptive teleosts

Siluriformes. The lateralis area in the Siluriformes consists of two longitudinal cell columns, a medial and a lateral (Figs. $2 \mathrm{C}, 3 \mathrm{~m}$ ). The medial cell column contains a nucieus medialis rostrally and a nucleus caudalis posteriorly, and thus resembles the single lateralis column of $A m i a$ and nonelectroreceptive teleosts, and the lateral cell column of chondrosteans and polypteriforms (Figs. 2A,B).

The lateral cell column of siluriforms is composed of a single nucleus termed here the lateral line lobe. The lateral line lobe occupies the rostral two-thirds of the lateralis area and, like nucleus medialis, is covered dorsally by the cerebellar crest. In Sorubim lima, the lateral line lobe contains large biopolar celis $\{30$ $\mu \mathrm{m}$ in diameter $)$, round cells $(20 \mu \mathrm{m}$ in diameter), and smaller cells of similar mor. phologies.

No nucleus or cell column in either the nonelectroreceptive teleosts, holosteans, chondrosteans, or polypteriforms corresponds to the lateral line lobe of siluriforms. In light of the similarity of the medial cell column of siluriforms (nucleus medialis and nucleus caudalis) to the lateralis area of nonelectroreceptive species (such as Amia\}, it is likely that this cell column is associated with the mechanoreceptors and that the lateral line lobe of siluriforms is associated with the presence of electroreceptors. While there are no experimental anatomical studies of the central projections of mechanoreceptive and electroreceptive lateralis fibers in siluriforms, there is electrophysiological evidence that electroreceptive fibers terminate either exclusively, or along with mechanoreceptive input, in the lateral line lobe (Andrianov and Ilyinsky, '73; McCreery, '77).

Mormyriformes. 'The mormyriforms possess a very complexly organized lateralis area. In 

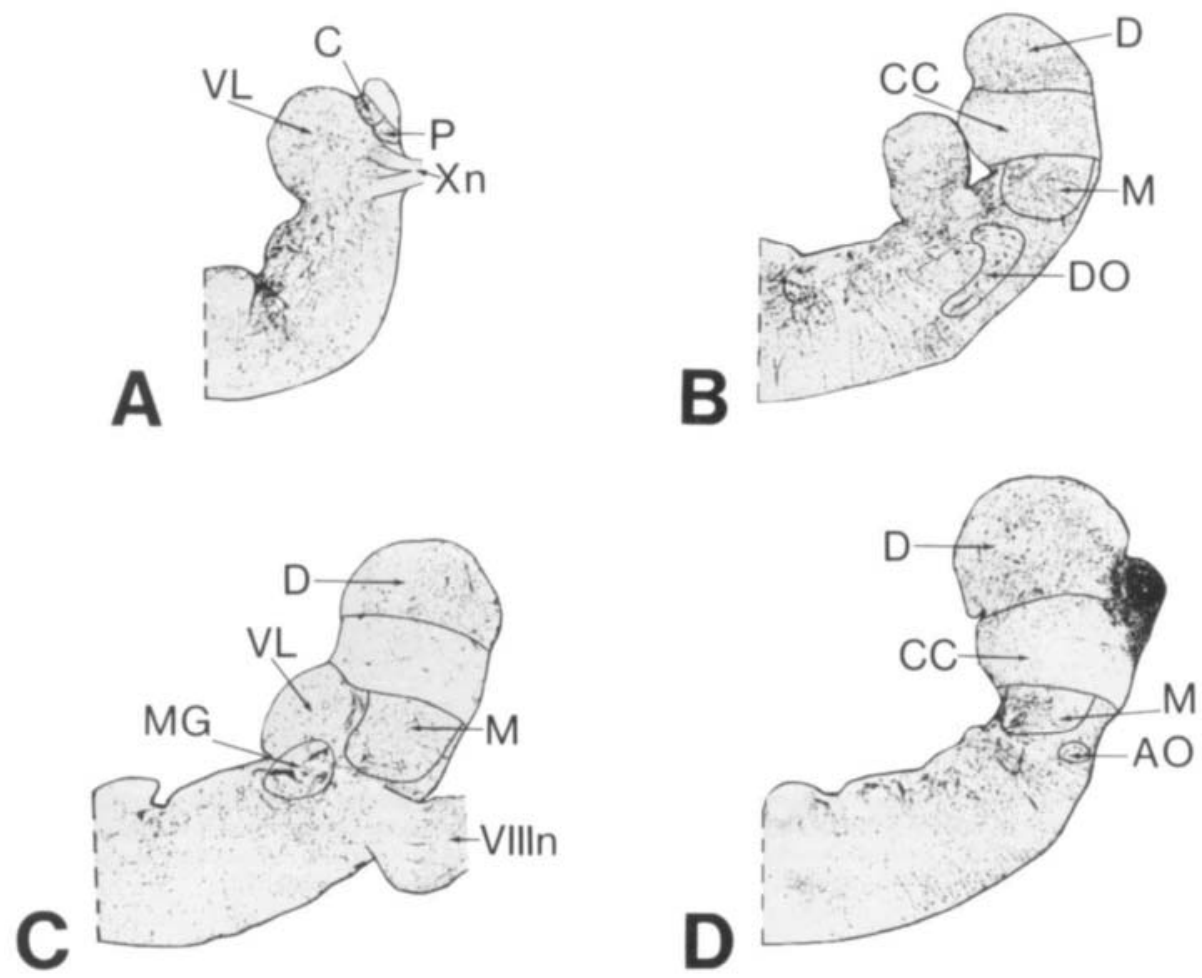

Fig. 5. Photomicrographs of transverse sections through the octavolateralis area of Scaphirhynchus platorynchus; A is the caudalmost section. Cresyl violet. Abbreviations: AO, anterior octavus nucleus: C, nucleus caudalis: CC. cerebellar crest: D, nucleus dorsalis; DO, descending octavus nucleus: $M$, nucleus medialis; $M G$, nucleus magnocellularis; $P$, posterior octavus nucleus: VIIln, eighth nerve: VL, vagal lobe: Xn. vagus nerve.

these fish, the dorsolateral portion of the octavolateralis area is greatly hypertrophied and forms a laminated structure that is fused across the midline. This structure, the posterior lateral line lobe of others, is termed here simply the lateral line lobe (Fig. 7A-E). The medial portion of the lateralis area, consisting of nucleus medialis and nucleus caudalis, lies ventromedial to the lateral line lobe and is likewise fused at the midline (Fig. 7B-E). The organization of the lateral line lobe has been described extensively by others (Maler, 73, '79; Maler et al., '73a; Bell and Russell, '78) and has been shown to be the termination site of first-order electroreceptive input in the mormyrid Gnathonemus petersi (Bell and Russell, 78). The medial column, which receives primary lateralis mechanoreceptive and eighth nerve input (Maler et al., "73a, b; Bell and Russell, '78; Bell, ' 811 , is described below.

Caudally in the octavolateralis area, the cerebellar crest overlies a population of granule cells, which I believe correspond to the nucleus caudalis and posterior octavus nucleus (dis- cussed in a later section) of other fishes. The granule cell population can be tentatively subdivided into a compact dorsal division, or nucleus caudalis, and a ventral division, or posterior octavus nucleus (Fig. 7A); the boundaries betwen these two nuclei are less well defined in Gnathonemus than in the other species studied here.

Rostral to these granule cells, the cerebellar crest overlies a nuclear group that has as its dorsalmost component Purkinje-like cells; I consider the appearance of these cells to mark the caudal boundary of nucleus medialis. As in other fish, nucleus medialis contains multipolar, fusiform, and granule cells ventral to the Purkinje-like cells and, for nearly the entire extent of nucleus medialis in Gnathonemus, this ventral population is itself dramatically separated into dorsal and ventral portions by the efferent tract of the lateral line lobe $/ F i g$. $7 \mathrm{~B}-\mathrm{D}$.

This description of the lateralis area in Gnathonemus is in contrast to those of recent experimental investigations of the mormyrid 

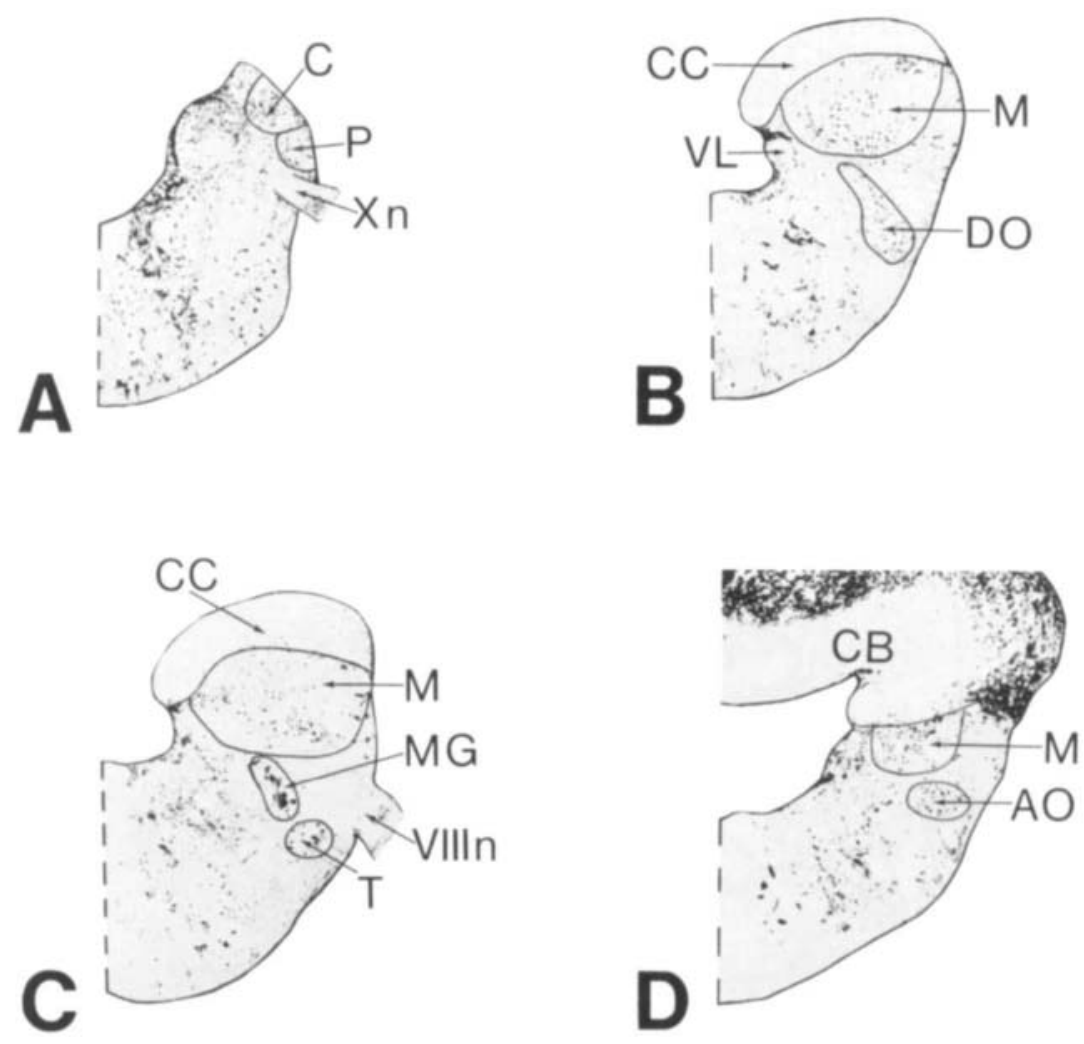

Fig. 6. Photomicrographs of transverse sections through the octavolateralis area of Salmo gaindneri; $A$ is the caudalmost section. Cresyl violet. Abbreviations: $A O$, anterior octavus nuclusus; $C$. nucleus caudalis; $C B$, cerebellum; $C C$. cerebellar crest; DO, descending octavus nucleus; EG, eminentia granularis; $M$, nucleus medialis; MG, nucleus magnocellulariș; P. posterior octavus nucleus: ' $\mathrm{T}$, nucleus tangentialis; VIIIn, eighth nerve; $V \mathrm{~L}$, vagal lobe; $\mathrm{Xn}$, vagus nerve.

octavolateralis area, as will be discussed in a later section.

\section{Organization of the octavus area in actinopterygians}

The octavus cell column in actinopterygians does not exhibit as much variation in its basic organization as does the lateralis cell column (Fig. 8). The four first-order octavus nuclei that were experimentally defined in Amia (Fig. 1) (McCormick, '78, '81) were identified in all of the species I surveyed (Figs. 4-8). Additional$\mathrm{ly}$, a fifth cell group, nucleus tangentialis, was observed in teleosts, but not in other actinopterygian groups (Figs. 6C, 7C, 8h).

Anterior octavus nucleus

A cell population comparable in position and morphology to the anterior nucleus in Amia was at least tentatively identified in the species listed in Table 4. The anterior nucleus (Figs, 1D, 4D, 5D, 6D, 7E, 8d,h) consists of a group of fusiform cells situated rostral to the entering anterior eighth nerve ramus and ventral to nucleus medialis. Identification of this nucleus was difficult in my Gnathonemus material: here, the anterior nucleus I recognize is closely apposed to the ventral boundary of nucleus medialis. An eighth nerve input is reported to the anterior nucleus in three actinopterygians (McCormick, '78, '81: Northcutt, '79b; '80; Bell, "81) (see Table 5). On the basis of the study of Bell (81), the medial portion of the anterior nucleus in mormyrids appears to receive a specific first-order input from the sacculus, although lagenar, utricular, and lateralis fibers overlap in the lateral portion of this nucleus.

\section{Nucleus magnocellularis}

Nucleus magnocellularis (Figs, $1 \mathrm{C}, 4 \mathrm{C}, 5 \mathrm{C}$, $6 \mathrm{C}, 7 \mathrm{D}, 8 \mathrm{c}, \mathrm{g})$ is found at the level of entrance of the eighth nerve, caudal to the anterior octavus nucleus. Its cells are typically large and multipolar, and stain darkly with cresyl violet. In nonteleost actinopterygians, nucleus mag. nocellularis is positioned close to the sulcus limitans, and its cells may be as large as $60 \mu \mathrm{m}$ in diameter. In teleosts, the cells of this nucleus occupy a more lateral position, although in some species these cells are found more dorsally at some levels within the bound- 

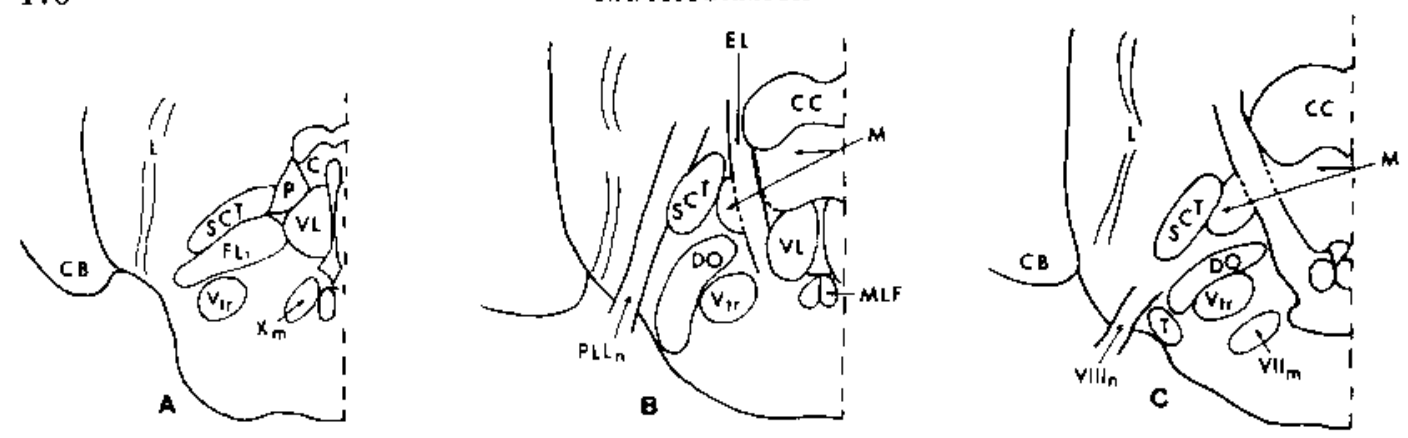

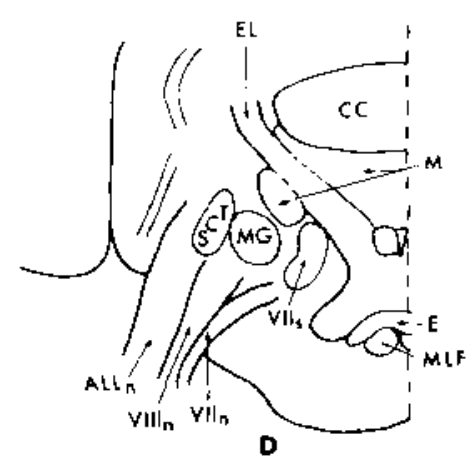

Fig. 7. Line drawings of transverse sections through the octavolateralis area of Gnathonemus petersi. Abbreviations: $A L L_{n}$ anterior lateral line nerve; $A O$. anterior $o c$. tavus nucleus: $A O_{L}$, a lateral specialization of the anterior octavus nucleus: $C$. nucleus caudalis; $C B$, cerebellum; CC. cerebellar crest: DO, descending octavus nucleus; $E$, efferent cells of the lateral lime nerves; EL. efferent tract of the lateral line lobe: $\mathrm{FL}_{1}$, lateral funicular nucleus 1; GP. ganglion mesencephalicus praeeminentalis: L, lateral line

aries of nucleus medialis. Additionally, in some teleosts, such as Gnathonemus, the cells of nucleus magnocellularis are considerably smaller ( $30 \mu \mathrm{m}$ in diameter) than those of nonteleost actinopterygians. Nucleus magnocellularis has a short rostrocaudal extent, and is replaced caudally by the descending octavus nucleus. Although nucleus magnocellularis receives a small input from the anterior lateralis nerve in some species (McCormick, '78, '81; Northcutt, ' 80 ; Bull, ' 81 ) (see T'able 5), its major primary input is from the eighth nerve (McCormick, '78, '81; Northcutt, '79b, '80; Bell, '81). On the basis of work by Bell ('81), the nucleus magnocellularis in Gnathonemus - as delineated in the present study - appears to receive input largely from the utriculus and semicircular canals, although fibers from other endorgans also terminate sparsely in this structure.

\section{Descending octavus nucleus}

The descending octavus nucleus (Figs. 1B, $4 \mathrm{~B}, 5 \mathrm{~B}, 6 \mathrm{~B}, 7 \mathrm{~B}, \mathrm{C}, 8 \mathrm{~b}, \mathrm{f})$ is the largest compo-

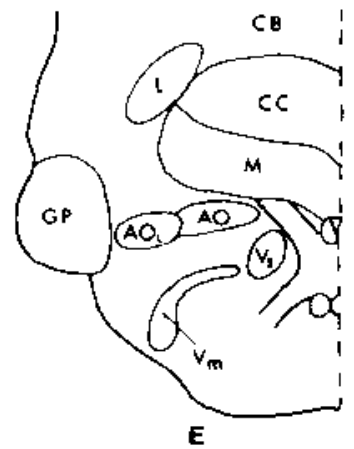

lobe: $M$. nucleus medialis; $M G$, nucleus magnocellularis: MLF, medial longitudinal fasciculus; $P$, posterior octavus nucleus; PLL ${ }_{n}$ posterior lateral line nerve: SCT, spino. cerebellar tract: $T$, nucleus tangentialis: $V_{n}$, trigeminal motor nucleus; $V_{s}$, sensory nucleus of the trigeminal nerve; $V I I_{n}$, facial nerve: VIJI $I_{n}$, eighth nerve; VII ${ }_{m 1}$, facial motor nucleus: $\mathrm{VII}_{\mathrm{s}}$, sensory nucleus of the facial nerve: $V_{t I}$ descending tract of the trigemingl nerve: VL, vagal Jobe: $\mathrm{X}_{\mathrm{m}}$, molor nucleus of the vagus nerve.

nent of the actinopterygian octavus cell column. This nucleus consists primarily of fusiform cells that freq ently form a crescentshaped cluster ventral to the more darkly staining, and often larger, cells of nucleus medialis. It extends from a level just caudal to the entering eighth nerve rami to the region of entrance of the glossopharyngeal nerve. A primary octavus projection to the descending nucleus has been reported in several experimental studies (McCormick, '78, '81; Northcutt,'79b, '80; Bell, ' 81 ) and in mormyrids this projection has been shown to originate, for the most part, from the utriculus and semicircular canals (Bell, '81).

\section{Posterior octavus nucleus}

The posterior octavus nucleus (Figs. 1A,4A, $5 \mathrm{~A}, 6 \mathrm{~A}, 7 \mathrm{~A}, 8 \mathrm{a}, \mathrm{e}$ ) contains small, loosely packed granule cells that are in most cases positioned on the lateral aspect of the medulla ventral to nucleus caudalis. In Gnathonemus, the posterior octavus nucleus is found medial to the ventrolateral portions of the lateral line lobe, 

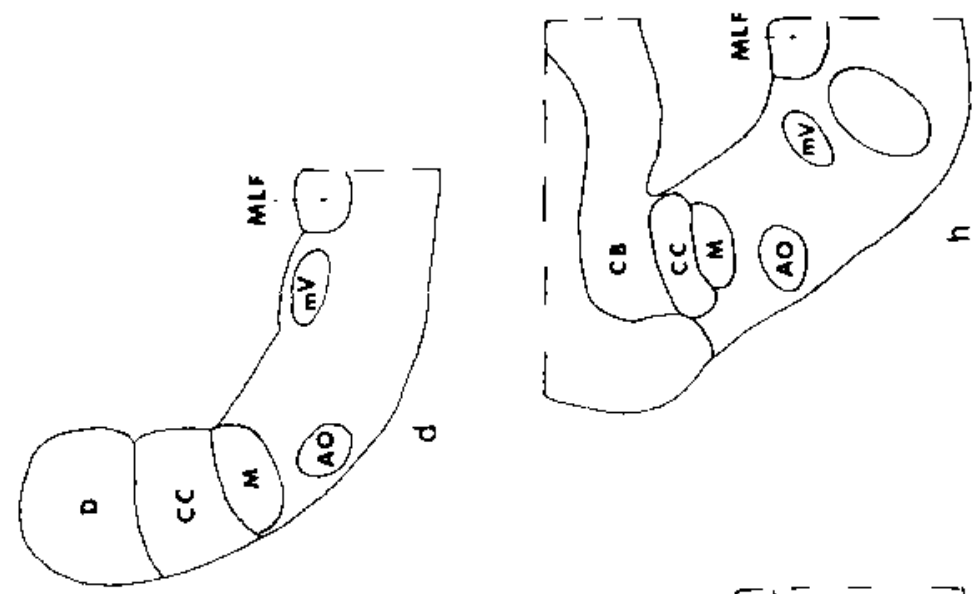

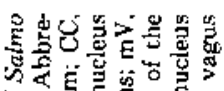

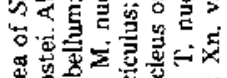

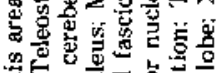

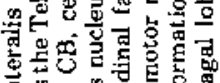

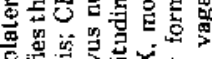

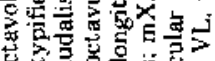

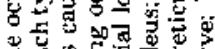

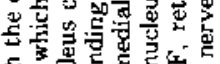

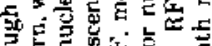

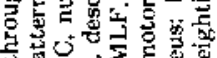

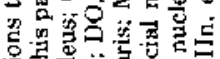

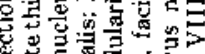
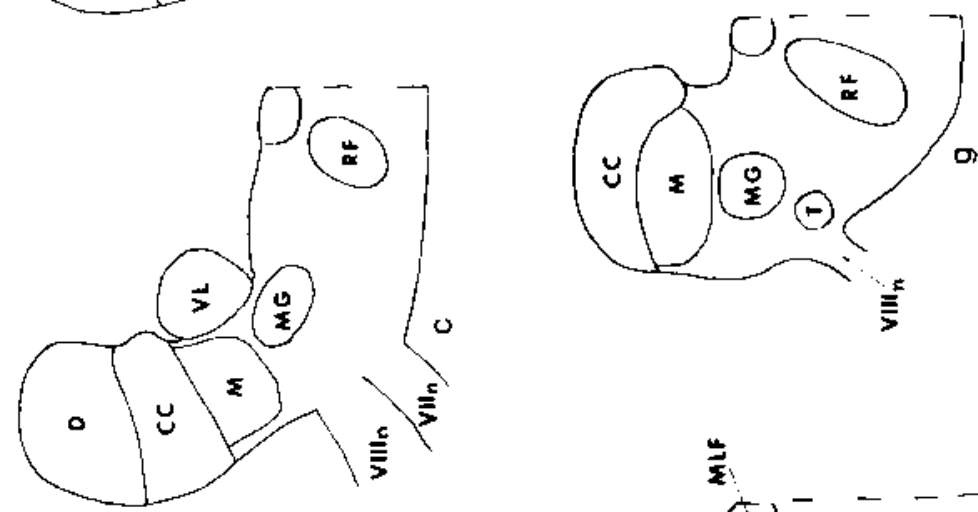

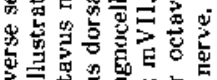

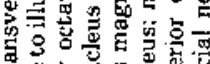

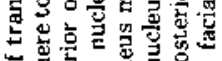

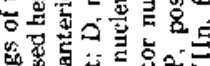

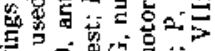

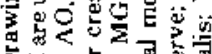
额

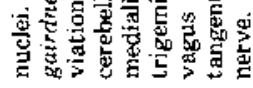
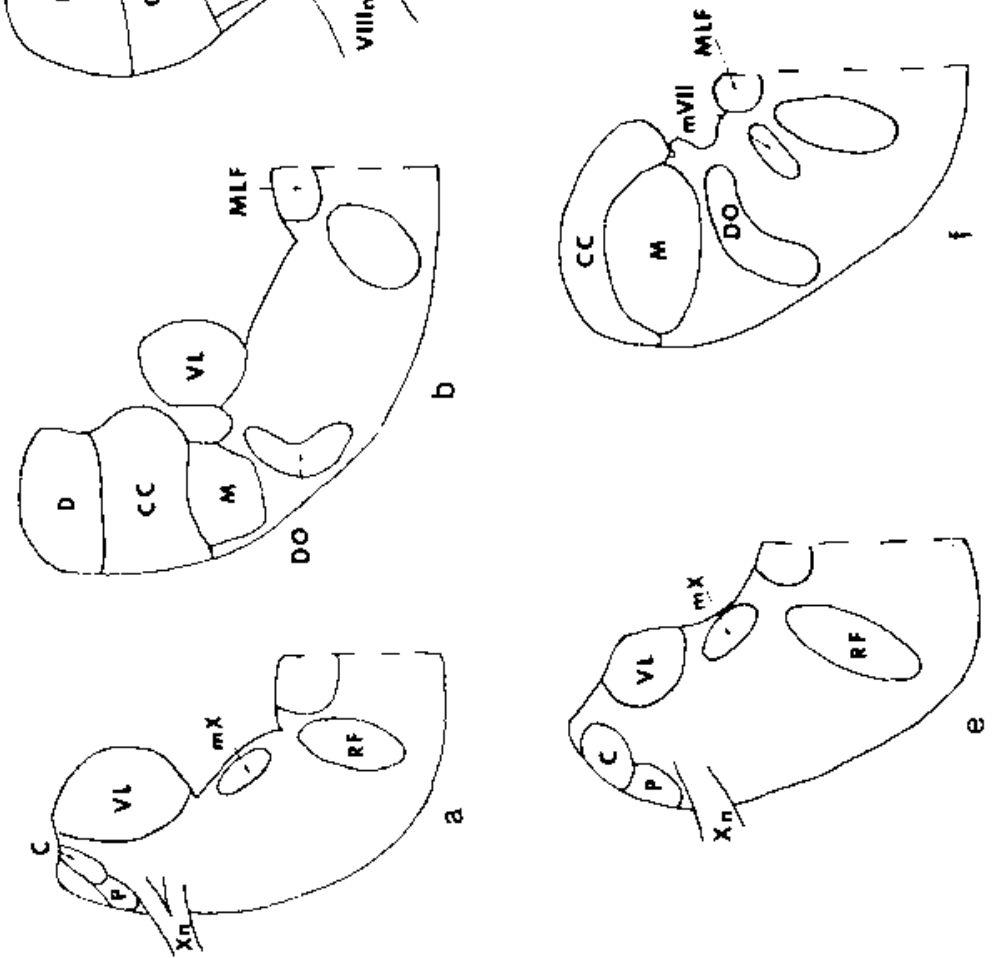

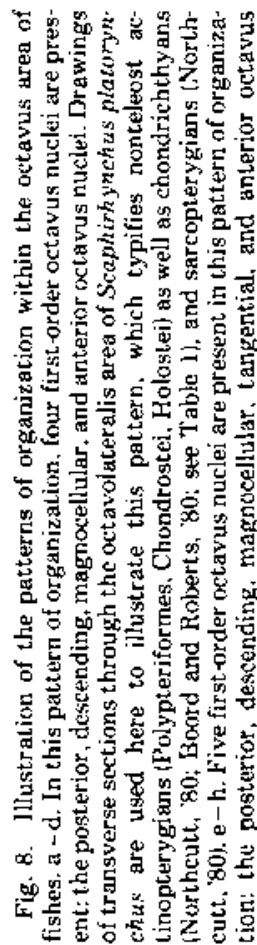


TABLE 4. Suntmary of the first order octavus nuclei of fishes recognized by carious investigators *

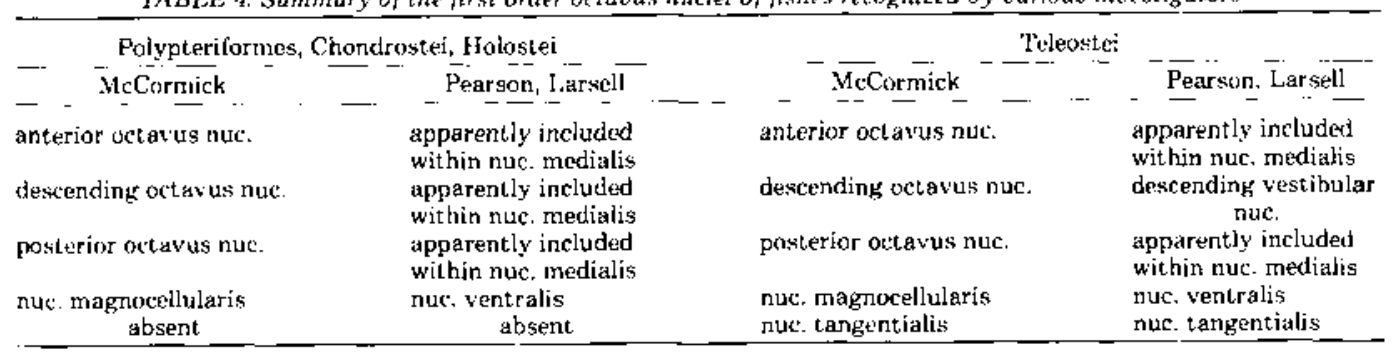

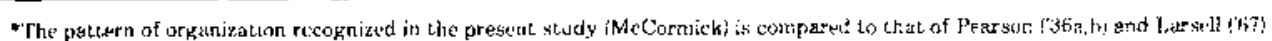

TABLE.5. The orgunization of the trctavoluteralis area in the mormyrid Gnathonenus petersi*

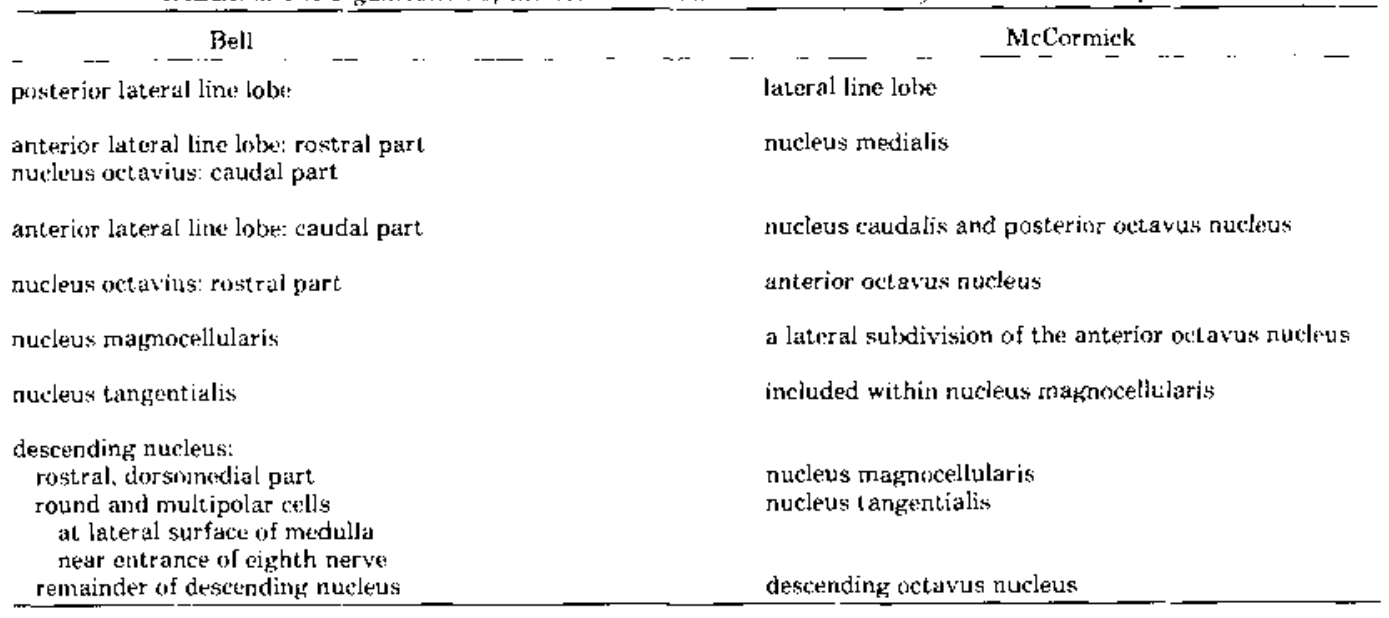

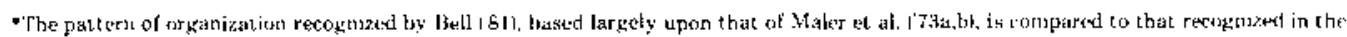
present study IMecormickl.

and, as previously mentioned, the boundary between the posterior nucleus and nucleus caudalis recognized here is a tentative one. A]though the posterior octavus nucleus was included within the nucleus medialis of many previous studies (e.g., Pearson, '36a,b; Larsell, 67; Bell, 81), I recognize it as a structure distinct from nucleus medialis in all species I surveyed. Fighth nerve afferents have been traced to the posterior octavus nucleus in three actinopterygians (McCormick, '78, '81; Northcutt, '79b, '80: Bell. '81) (see Table 5), and mechanoreceptive lateralis afferents also ap. pear to terminate here in mormyrids (Bell, 81 ).

\section{Nucleus tangentialis}

In addition to the four octavus nuclei de scribed above, I recognized nucleus tangentialis as a distinct cell group only in the teleosts (Figs. 6C, 7C, 8g). This is in agreement with the observations of other investigators (Pearson,'36a,b: Larsell,'67). The cells of nucleus tangentialis are similar in morphology to those of the teleostean nucleus magnocellularis; they are large and darkty staining multipolar cells. Nucleus tangentialis is located near the lateral edge of the medulla in the vicinity of the entry of the eighth nerve and input to it from this nerve has been demonstrated in two teleosts (Northcutt, '79b, '80; Bell, '81). In mor. myrids, Bell's study ('81) (see Table 5) suggests that the utriculus and semicircular canals are the major source of these fibers.

\section{DISCUSSION}

\section{Organization and evolution of the lateralis area}

Figures 2 and 3 illustrate that aithough three patterns of organization can be recog- 
nized within the lateralis area, certain common features are also present. In the actinopterygians examined in this study, as well as in petromyzontid agnathans (Fig. 3a, Table 1) and chondrichthyans (Figs. 3b,c, Table 1). the lateralis area always contains one cell column comprised of nucleus medialis and, with the exception of petromyzontids, nucleus caudalis. The apparently universal presence of this cell column likely reflects the universal presence of the mechanoreceptors of the lateral line system. Not only does this column constitute the entire lateralis area of nonelectroreceptive fishes, it is also the site of first-order mechanoreceptive, but not electroreceptive, input in at least some electroreceptive species (Maler et al., '74; Boord and Campbell, '77; Bell and Russell, '78; Bodznick and Northcutt, '80). In addition, nucleus medialis has been shown electrophysiologically to be involved in mechanoreceptive processing in the nonelectroreceptive teleost Carassius (Russell, '76; Caird, '78). If nucleus medialis and nucleus caudalis are, as is hypothesized here, central correlates of the mechanoreceptors of the lateralis system in all fish, each of these nuclei is likely homologous among fish, since the lateralis system is not thought to have been derived independently in different taxa. It can be suggested that additional nuclei within the lateralis cell column signal the presence of further functional subdivisions of the lateralis system. Nucleus dorsalis and the lateral line lobe, for example, apparently reflect the presence of electroreceptors.

Although there are no experimental analyses of primary inputs to the octavolateralis area in polypteriforms and chondrosteans, such studjes are available for species of petromyzontid agnathans and chondrichthyans. Figures 2 and 3 illustrate that the lateralis areas of these four groups of fish are virtually identical in their organization. Thus, the lateralis area of petromyzontids and chondrichthyans contains a dorsomedial differentiation, nucleus dorsalis, which is associated with the dorsal ramus of the anterior lateral line nerve, in addition to a lateral column containing nucleus medialis and, with the exception of petromyzontids, nucleus caudalis. In these fish, the dor sal anterior lateralis ramus supplies nucleus dorsalis, and the ventral anterior lateralis ramus and the posterior lateralis nerve supply nucleus medialis and nucleus caudalis (Boord and Campbell, '77; Northcutt, '80). This pattern of inputs is similar to that described in nonex- perimental studies of polypteriforms and chondrosteans (Johnston, '01; Larsell, '67; van der Horst, '25). Anatomical studies in chondrichthyans concluded that the dorsal anterior lateralis ramus is likely composed of fibers from the electroreceptors, whereas the ventral anterior lateralis ramus and the posterior lateralis nerve appear to carry only mechanoreceptive input (McCready and Boord, '76), a dichotomy recently confirmed physiologically (Bodznick and Northcutt, ' 80 ). Thus, the functional subdivison of the lateraljs system into mechanoreceptive and electroreceptive portions is reflected, at least in chondrichthyans, by the presence of two lateralis cell columns: a medial (nucleus dorsalis) electroreceptive column and a lateral (nucleus medialis and nucleus caudalis) mechanoreceptive column.

It is hypothesized that such a functional subdivision is the basis for the common organizational pattern of the lateralis area shared by petromyzontid agnathans, chondrichthyans, polypteriforms, and chondrosteans isee also McCormick, '78). That is, like the nucleus dorsalis of chondrichthyans, the nucleus dorsalis of these other taxa is likely a first-order electroreceptive nucleus supplied by the dorsal ramus of the anterior lateral line nerve, whereas nucleus medialis and nucleus caudalis are, as in chondrichthyans, first-order mechanoreceptive nuclei. Electroreceptors or an electroreceptive ability had previously been described in at least some members of all of these taxa (Pfeiffer, '68; Jorgenson et al., '72; Teeter and Bennett, '76) with the exception of petromyzontids, although weak current generation had been reported in the latter group (Kleerekoper and Sibakin, '56a,b, '57) and electroreception in fossil agnathans had been hypothesized (Thompson, '77). That petromyzontids are electroreceptive, as was predicted on the basis of the presence of nucleus dorsalis (McCormick, '78), has recently been confirmed electrophysiologically, and the medullary electroreceptive area has, in fact, been localized to nucleus dorsalis (Bodznick and Northcutt, '81). Thus, if the above hy pothesis is correct, the presence of a nucleus dorsalis may be taken as an indicator of electroreceptive ability. In addition, since petromyzontids, chondrichthyans, polypteriforms, and chondrosteans share a common organizational pattern of the lateralis area, it is hypothesized (McCormick, '78) that this pattern, along with electroreception, developed early in vertebrate history i.e., in a population ancestrai to petromyzontids and gnathostomes. 
Nucleus dorsalis is absent in the holosteans Amia (McCormick, '78, '81) and Lepisosteus and in all teleosts that were examined in this study. The lateralis area of nonelectroreceptive fishes, which include holosteans and the majority of teleosts, contains only nucleus medialis and nucleus caudalis, i.e., the lateralis structures hypothesized to be mechanorereceptive areas in all fishes. On the basis of the taxonomic distribution of nucleus dorsalis (Figs, 2, 3), it is further hypothesized that nucleus dorsalis, and thus electroreception, were both lost sometime between the chondrostean and teleostean radiations.

Electroreception is thought to have evolved independently in each teleost family showing electroreceptivity (Bullock, 74), a hypothesis that is consistent with the phylogeny of these fishes (Greenwood, "73) (Fig. 3. Table 2). Not only is the organization of the electroreceptive lateralis area in these teleosts different from that of earlier radiations of electroreceptive fishes (Figs. 2A,C), but also it differs among various electroreceptive teleost families themselves in terms of its innervation and internal organization (e.g., Maler, '73, '79; Maler et al., 73a,b, 74; Rethelyi and Szabo, 73). In those teleosts known to be electroreceptive, the lateral or dorsolateral portion of the lateralis area is hypertrophied and forms the lateral line lobe. In species belonging to two of these families, the Mormyridae and the Gymnotoidae, the lateral line lobe receives first-order electroreceptive, but not mechanoreceptive, input (Maler et al., 74; Bell and Russell. '78), and this structure is known to participate in electroreceptive processing in the third family, the Siluridae (Andrianov and Ilyinsky, "73: McCreery, '77). The lateral line lobe is both cytologicaliy and topographically different from the nucleus dorsalis of earlier radiations, is not invariably associated with a dorsal ramus of the anterior lateral line nerve, and is considered here to be homoplasic to nucleus dorsalis (i.e., the two structures evolved independently). In addition, since the nucleus dorsalis is a dorsomedial differentiation of the lateralis area, whereas the lateral line lobe is a dorsolateral differentiation of this area, topological criteria also indicate that they are nonhomologous structures (Nieuwenhuys, '74).

In summary, the three patterns of organization in the lateralis area described in this report may be attributable to the presence of an electroreceptive portion of the lateralis system in primitive fishes (Figs. $2 \mathrm{~A}, 3 \mathrm{a}-\mathrm{e}$ ), its loss in later actinopterygian radiations (Figs. 2B, $3 \mathrm{f}, \mathrm{h}, \mathrm{i}, \mathrm{j}, \mathrm{k} \mathrm{k}$, and its subsequent redevelopment in certain teleost families (Figs. 2C, $3 \mathrm{~g}, \mathrm{l}, \mathrm{m}$ ).

\section{Comparisons with other investigations}

Morphological descriptions of the lateralis area. Earlier discussions of the lateralis area based on nonexperimental material (e.g., Pearson, '36a, b; Larsell, ' 67 ) were frequently vague in their descriptions of its constituent nuclei. The major difference between these studies and the present study, apart from nomenclature and evolutionary hypotheses, both of which are discussed below, concerns the boundaries of the cell group that is comparable to the nucleus medialis described in this report. These studies generally considered nucleus medialis to extend farther ventrally and caudally than the nucleus medialis defined here. As a result, the nucleus medialis of older studies encompasses nucleus caudalis, possibly structures caudal to this cell group, and portions of the octavus cell column. This difference in boundaries undoubtedly contributed to the consistent finding of eighth nerve input in to nucleus medialis in these older studies. a projection that has not been experimentally verified in the majority of fishes studied to date (Table 1 ).

There have been several experimental analy. ses of the afferent connections of the octavolateralis area in actinopterygians. Northcutt ('79b, '80) described only nucleus medialis and nucleus caudalis in the lateralis column of Gillichthys, a finding consistent with the absence of an electroreceptive ability in this species, and found that the eighth nerve did not terminate within this column. In the electroreceptive gymnotid Apteronotus, medullary lateralis afferents were traced only to the nuclei of the lateralis cell column, with electroreceptive fibers terminating in the lateral line lobe for posterior lateral line lobel (Maler et al.. '74) and mechanoreceptive fibers terminating in nucleus medialis (or anterior lateral line lobe) (Maler et al., '74). The afferent connections of the octavolateralis area have been most widely studied in the electroreceptive mormyrid Gnathonemus (Maler et al., "73a,b; Bell and Russell, '78: Szabo et al., '78, '79; Bell, '81). My analysis of the organization of this area differs markedly from many of these reports isee Results; Fig. 7). The most extensive of these studies (Bell, '81) primarily employs the nomenclature and boundaries introduced by Maler et al. $(13 \mathrm{a}, \mathrm{b})$, and subdivides the dorsal portion of the octavolateralis area into a posterior and an anterior lateral line lobe and a nucleus octavius. Although the posterior lateral line lobe (an electroreceptive area) corresponds to the lateral line lobe of the present study, the anterior lateral line lobe and nucleus 
octavius (mechanoreceptive areas) appear to be composites of several nuclei that I recognize in the octavolateralis area of this species. Bell (81) reports that the caudal portion of the anterior lateral line lobe consists of a population of granule cells (Fig. $3 a$ in Bell, '81); I consider these cells to correspond to the nucleus caudalis and posterior octavus nuclei of other fishes. It appears that both of these nuclei receive primary afferent fibers from the eighth and lateralis nerves (Figs. 3a, 4a, 6a, 8a, in Bell, '81); overlap of these inputs appears to characterize the octavolateralis area of this fish (Table 1). As stated in Results. I consider the appearance of the Purkinje-like cells, or crest cells (Maler et al., '73a) to mark the caudal boundary of nucleus medialis. Bell, and others, term the cells lying ventral to the crest cells the anterior nucleus, and they consider the ventral border of this nucleus, and thus the anterior lateral line lobe, to be defined for much of its extent by the efferent tract of the (posterior) lateral line lobe (e.g., Fig. 3b-d in Bell, '81). The population of cells lying ventral to this tract, and dorsal to the descending nucleus (Bell, ' 81 ), is termed nucleus octavius \{e.g., Fig. 3b-d in Bell, 81). I consider the cytological similarities between nucleus octavius, throughout its caudal two-thirds, and nucleus anterior to indicate that together they correspond to the ventral portion of nucleus medialis in other fish. This interpretation is supported by the fact that the primary afferent connections to this portion of nucleus octavius arise largely from lateral line mechanoreceptors, although the lagena and utriculus also appear to project sparsely to it (Bell, '81). The pattern of inputs to the rostral part of nucleus octavius is quite different. Several endorgrans (utriculus, lagena, and lateralis mechanoreceptors) have substantial projections to the rostrolateral portion of nucleus octavius, whereas the rostromedial portion of this nucleus receives an exclusive, bilateral projection from the sacculus (Bell, 81). The rostral portion of nucleus octavius may correspond to the anterior octavus nucleus in other fish and will be discussed in a later section. In summary. I subdivide the anterior lateral line lobe of previous studies into a caudal portion, which includes nucleus caudalis and the posterior actavus nucleus, and a rostral portion. The rostral portion encompasses, using the terminology of Maler and Beil, the crest (Purkinje-like) cells and anterior nucleus and, along with most of nucleus octavius, corresponds to the nucleus medialis of other fish.
Organizational trends recognized in other comparative investigations of the lateralis area. The interpretation of the lateralis area presented here is summarized in Table 3 , where it is compared to the interpretations of Pearson ('36a,b), l,arsell ('67), and Maler ('74). In each of these investigations a different set of criteria was used to compare the lateralis nuclei. These criteria are briefly described below for the purpose of comparison with the present study. A more complete account can be found elsewhere (McCormick, '78).

Pearson based his interpretation of the lateralis nuclei on their topography and innervation. Among the actinopterygians he recognized a medially situated nucleus dorsalis and a laterally situated nucleus medialis only within the chondrosteans, and he also identified these nuclei in petromyzontid agnathans and chondrichthyans. (As previously stated, nucleus caudalis is included within the nucleus medialis of all nonexperimental studies that precede the present analysis.) He considered nucleus dorsalis to be absent in holosteans and teleosts, and recognized only nucleus medialis in these groups. Pearson subdivided the nucleus medialis into dorsal and ventral (Amia) or medial and dorsal portions (Carassius, siluriforms) in some species. Although I consider these subdivisions to be absent in Amia and Carassius, those in siluriforms largely correspond to the two lateralis cell columns i have described (Table 3; Figs. 2C, 3m). Thus, Pearson's nucleus medialis pars medialis in siluriforms corresponds to the nucleus medialis of the present study, whereas his nucleus medialis pars dorsalis corresponds to the lateral line lobe. Importantly, Pearson did not relate either of his two subdivisions of the siluriform nucleus medialis to the nucleus dorsalis of chondrosteans, chondrichthyans, and petromyzontids (Table 3), and he thus recognized two patterns of organization within the lateralis area. It can be seen in Table 3 that of the three investigators, Pearson's interpretation of the lateralis area is most similar to that of the present study.

In contrast to Pearson, Larsell (67) recog. nized a single organizational pattern within the lateralis area of all fish in which both nucleus medialis and nucleus dorsalis are present. He employed topographic relationships between the subdivisions of the vestibulolateral lobe of the cerebellum and those of the lateralis area as his primary criterion in interpreting this area. This method of comparison is based on a presumed developmental continuity between the somatic sensory portion of 
the medulla and the vestibulolateral lobe (Johnston, '02). In chondrichthyans, Larsell claimed that the medial portion of the vestibulolateral lobe (the auricle) is continuous with the medial lateralis cell column (nucleus dorsalis). Similarly, the laterally situated eminentia granularis of the cerebellum was considered to be continuous caudally with the lateral cell column (nucleus medialis). Because Larsell believed these topographic relationships to be comon to all fish, he thereby defined a medially positioned nucleus dorsalis and a laterally positioned nucleus medialis in all fish (Table 3), at least in their larval stages.

Although Larsell's method of defining the lateralis area is an interesting one, neither cytoarchitectural analyses (Pearson, '36a,b; present study), nor the experimentally defined connections of the lateralis nuclei support the recognition of a single organizational pattern within the lateralis area. As stated previously, there is no structure in holosteans or teleosts comparable in its morphological characteristics to the nucleus dorsalis of chondrichthyans and other early radiations. Further, since the homologies of the subdivisions of the vestibulolateral lobe of chondrichthyans and actinopterygians are by no means certain. the use of these subdivisions to define medullary nuclei is tenuous.

Finally, Maler's interpretation of the lateralis area is similar to that of Larsell in that both nucleus dorsalis and nucleus medialis are considered to be present in chondrichthyans and teleosts, and to be caudal continuations of the auricle and eminentia granularis, respectively. However, unlike Larsell, Maler defines these nuclei using a single topographical feature - their contiguity with a given portion of the vestibulolateral lobe-without considering their relative positions in the medulla. Thus, based upon his interpretation of the highly specialized cerebellum of mormyrids and gymnotids, his homologization of the lateralis nuclei of these fish is opposite that of Larsell (Table 3); in other words, Maler's nucleus dorsalis (posterior lateral line lobe) occupies a dor solateral, rather than a medial, position in the medulla. However, despite this difference, Maler, like Larsell, recognized a single organizational pattern within the lateralis area of fish.

To summarize, much of the variation in the nomenclature of the lateralis nuclei can be accounted for by considering the criteria different investigators have used when comparing these nuclei among fish. Clearly, each of the hypotheses presented in Table 3 was form- ulated under the constraints of the data available at that time. Although these data have increased significantly in the last few years, the hypothesis set forth in the present study, in which three patterns of orgenization reflecting functional subdivisions of the lateralis system are recognized, requires extensive verification and may well be altered as more species are surveyed.

\section{Organization and evolution of the octavus area}

There appears to be less variability in the organization of the actinopterygian octavus area, in terms of the number of constituent nuclear groups, than is present in the lateralis area. Figure 8 illustrates that actinopterygians possess at least four octavus nuclei - the anterior, magnocellular, descending, and posterior octavus nuclei - and that in teleosts, a nucleus tangentialis is also present. The four octavus nuclei common to actinopterygians have also been recognized in experimental studies of the octavus area in chondrichthyans (Northcutt, ' 80 ; Boord and Roberts, 80 ), and described in normal material in sarcopterygians (Northcutt, ' 80 ). In contrast, the octavus area of petromyzontid agnathans (Northcutt, '79a) is not readily comparable to that of chondrichthyans and osteich thyans. It consists of a smali-celled longitudinal nucleus, nucleus ventralis, which includes three aggregations of large cells, the anterior, intermediate, and posterior octavomotor nuclei.

At the present, there are few data concerning the central representation of the various otic endorgans in the octavus area, and thus the functional significance of the organization of the octavus area described here is largely unknown. In the mormyrid Gnathonemus, the tangential, descending, and magnocellular nuclei recognized in the present study appear to receive substantial projections from otic endorgans generally considered as vestibular - the utriculus and semicircular canals (e.g., see Lowenstein, '71). However, the magnocellular nucleus also receives extremely sparse input from the sacculus and lagena (Bell, '81), two otic endorgans presumed to be auditory (e.g., see Fay and Popper, ' 80 ), and from the anterior lateral line nerve (Bell, ' 81 ). On the other hand. the sacculus, which in mormyrids is associated with a sound pressure transducer and is on this basis thought to be specialized for sound reception (e.g., see Stipetic, '39: van Bergeijk, '67; Fay and Popper, '80), has a bilateral projection to an area that receives no other first-order eighth nerve or lateralis fibers (Bell, ' 81 ). As 
discussed in a later section, the cells in this area appear to be included within the anterior octavus nucleus recognized in the present study. Although it is possible to speculate that the differential projections of the otic endorgans within the octavus column in mormy. rids is typical of osteichthyans and chondrichthyans, the peripheral specializations of the octavolateralis system in mormyrids make such a speculation premature at this time. First, the distribution of octavolateralis afferents in mormyrids differs substantially from that in other actinopterygians and chondrichthyans (Table 1). The lateralis and octavus nerves each project to cell groups within both the lateralis and octavus cell columns. unlike the nearly total segregation of these inputs in other fishes (Table 1). The atypical and specialized projections of the otic endorgans to parts of the lateralis cell column in mormyrids raises the possibility that their projections within the octavus cell column are likewise specialized. Second, although the sacculus in Gnathonemus has an exclusive projection within the anterior octavus nucleus, such a discrete, nonoverlapping projection might not characterize fish in which the sacculus is not obviously specialized for sound reception. Along these lines, it would be of great interest to investigate the central organization of auditory and vestibular input in species in which other otic endorgans, such as the utriculus (e.g., the Clupeidae) (O'Connell, '55; Denton and Blaxter, '76; Popper and Platt, '79; Blaxter et al., '81), or the macula neglecta (e.g., chondrichthyans) (Tester et al., '72; Fay et al., "74; Corwin, '77, '78), are believed to function as auditory receptors. The central projections of the macula neglecta have never been determined experimentally in any fish, although this structure is present not only in chondrichthyans but also in at least many actinopterygians (Retzius, 1881).

It is also difficult at the present time to discuss the significance of the teleostean nucleus tangentialis. It is possible that nucleus tangentialis represents a poptiation of cells that has differentiated out of one of the other octavus cell groups, since teleosts possess the same number of otic endorgans as nonteleost actinopterygians and chondrichthyans. Northcutt (80) has described the nucleus tangentialis in a goby, Gillichthys, as a lateral extension of nucleus magnocellularis. Correspondingly, the significant morphological differences between the otic endorgans of agnathans and later radiations of fishes (Lowenstein, '71) may at least partially account for the differences in the nuclear organization of the octavus column that exist between them.

In summary, four nuclei are common to the octavus cell column of chondrichthyans, actinopterygians, and sarcopterygians (Northcutt, ' 80 ) (Table 1): the anterior, magnocellular, descending, and posterior octavus nuclei. This pattern of organization likely arose in ancestral populations common to both chondrich. thyans and osteichthyans, and the four octavus nuclei are thus considered here to be homologous structures in these taxa. The octavus cell column exhibits at least three organizational patterns in terms of its constituent nuclear groups - that of petromyzontid agnathans, that of chondrichthyans and non. teleost osteichthyans, and that of teleosts. The functional significance of these three patterns remains to be elucidated. In addition, on the basis of its morphologically unique labyrinth (Lowenstein and Thornhill, '70; Lowenstein, 71), the octavus area of myxinoid agnathans, which is yet to be experimentally analyzed, may well display a fourth pattern of organization.

\section{Comparison with other investigations}

Morphological descriptions of the octavus area. The description of the octavus area presented here contrasts greatly with that of previous comparative studies (Pearson, '36a, b; Larsell, '67) (Table 4). These studies considered the octavus area of nonteleost actinopterygians, as well as chondrichthyans, to consist of a single nucleus ventralis, a structure that largely corresponds to the nucleus magnocellularis of the present study. In contrast, the octavus area of teleosts was thought to be much more differentiated than that of earlier radiations of fish, and the descending and tangential nuclei were recognized in addition to nucleus ventralis. One reason for the discrepancy between these studies and the present analysis may lie in differences in the definition of the boundaries of nucleus medialis. Nucleus medialis was considered in older analyses to extend further caudally and ventrally than is recognized here and in other recent studies (McCormick, 78, '81; Northcutt, '79b; Boord and Campbell, 77; Boord and Roberts, '80). and thus probably encompassed several of the octavus nuclei they describe.

The description of the octavus nuclei of the mormyrid Gnathonemus presented here is in partial agreement with that of Bell ('81) (Table 5). Although Bell did not recognize a posterior 
octavus nucleus, this cell group is likely included within the caudai portion of his anterior lateral line lobe (e.g., Fig. 3a in Bell, "81), since this region contains only small, spherical cells. From his chartings, it appears that first-order lateralis fibers terminate here along with octavus fibers, a condition not seen in chondrichthyans or holosteans (Table 1). As previously mentioned, the primary octavolateralis projections in mormyrids are markedly different from those of other species studied to date (Table 1), and probably represent a specialized case.

The nucleus octavius of Bell ('81). delineated on the basis of the initial studies of Maler et al. ('73a,b) in Gnathonemus, may in fact be a composite of two nuclear groups. As already mentioned, nucleus octavius is, except for its rostral portion, considered here to be the ven tralmost portion of the nucleus medialis. The rostral portion of nucleus octavius le,g., Fig. $3 \mathrm{f}$ in Bell, '81) appears to correspond to the anterior octavus nucleus I have tentatively delineated in Gnathonemus. Beli traced a bilateral projection of the sacculus to the medial part of this portion of his nucleus octavius, and lagenar, utricular, and mechanoreceptive lateralis input to its lateral part.

Bell's descending nucleus (e.g., Fig. 3b,c, in Bell, '81) largely corresponds to the descending octavus nucleus I recognize in Gnathonemus. He includes a nucleus tangentialis and a nucleus magnocellularlis in his figures (e.g., Figs. $3 \mathrm{e}, \mathrm{f}$, in Bell, ' 81 ) that are based upon those originally recognized by Maler et al. (73a,b). However, Bell states that these nuclei probably do not correspond to the magnocellular and tangential nuclei in other fish, and he speculates that portions of his descending nucleus may in fact include the magnocellular and tangential nuclei that have been recog. nized in other species. My observations agree with his suggestion. The tangential nucleus of Maler et al. (Fig, 4c in Maler et al., '73b; Fig. 3e in Bell, '81) appears to be at least partially included within the descending octavus nucleus I recognize in Gnathonemus. The nucleus magnocellularis of Maler et al. (Fig. 4a in Maler et al., '73b; Fig. $3 \mathrm{f}$ in Bell, ' 81 ), is not readily comparable to any of the octavus nuclei that have been experimentally defined in other actinopterygians (McCormick, '81; Northcutt, ${ }^{7} 79 \mathrm{~b}$, ' 80 ). This population of large cells, labeled AOL in Figure 7E, receives a heavy projection from the utriculus (Fig. $3 \mathrm{f}$ in Bell, ' 81 ) and abuts against the lateral border of the anterior octavus nucleus recognized in the present study.
Large cells are not present in this position in the ather actinopterygians surveyed in this study, and those in Gnathonemus are hypothesized here to represent a specialized portion of the anterior octavus nucleus.

Organizational patterns recognized in other comparative studies. Previous nonexperimental investigations recognized two patterns of organization within the octavus area: that of chondrichthyans and nonteleost osteichthyans and that of teleosts (Pearson, '36a,b; Larsell, '67). Whereas teleosts were thought to possess three octavus nuclei-the descending. ventral for magnocellular), and tangential nuclei-only nucleus ventralis was described in the octavus area of other gnathostome fishes. The present study, along with experimental analyses of the octavus area, indicates that although the organization of the octavus area in teleosts and nonteleost gnathostomes does differ, each of these groups possesses more octavus nuclei than were described in older studies. As stated previous. $l y$, this difference in the number of nuclei recognized is probably attributable to the fact that older studies recognized a very extensive nucleus medialis that probably included many of the octavus nuclei described here: these relationships are shown in Table 4.

\section{Additional considerations}

This discussion has, up to this point, centered on the patterns of variation seen within the octavolateralis area of actinopterygian, as well as other, fishes. However, equally important is the fact that for the most part, the general organization of the octavolateralis area appears to be more similar among different taxa than it is dissimilar. Major differences in central organization appear to be attributable to specific peripheral features that are not common to all taxa, such as the presence of electroreceptors. In light of the general similarity of the organization of the lateralis and octavus cell columns, one point that is open to speculation concerns predictions about the pattern of first-order afferent connections to these celi columns. As a whole. experimental studies of these connections indicate that the primitive pattern of primary afferent octavolateralis in. put is characterized by relatively little overlap of lateralis and octavus fibers (Table 1). That is, in agnathans, chondrichthyans, and $A$ mia, a holostean, first-order lateralis fibers iargely terminate within the dorsal lateralis cell column and the eighth nerve terminates in the octavus cell column. Does the delineation of sim. 
ilar cell columns among the various actinopterygian radiations imply that a similar pattern of connections will be found to characterize these taxa? It is suggested here that in at least many species this is likely to be the case, i.e.. that many groups of fish will be found that retain this generalized pattern of organization. On the other hand, it can be hypothesized that departures from this general pattern of inputs will be found to typify species that possess unique peripheral specializations that alter the basic functional characteristics of the lateralis and/or octavus systems. Such a specialization may explain the widespread central convergence of octavus and lateralis fibers in the mormyrids Gnathonemus and Brienomyrus (Bell and Russell, '78; Bell, '81: Table 1). In these fish, there is a great deal of overlap in the termination sites of the lateralis and eighth nerves within the octavolateralis area. Mormyrids possess bilateral air sacs that abut against the labyrinth and that have been postulated to act as sound pressure transducers (e.g., Stipetic. '39; van Bergejik, '67; Fay and Popper, '80). Because the air sacs are also continuous with the head canals of the lateral line system (Greenwood, '73). there is a possibility that oscillations of the air sacs as a result of sound pressure waves could stimulate both otic and lateralis receptors. Since this mode of stimulation is not thought to typify the lateralis systern of most other fish (e.g., Sand, ' 81 ), and could conceivably confer a marked sensitivity to sound upon the lateraiis system, the peripheral specializations in mormyrids might provide an explanation for the specialized, and thus far unique, pattern of octavolateralis inputs in these fish. A study of the responsiveness of the lateralis system to sound pressure in mormyrids would therefore be of great interest. Along these same lines, specializations in the connectivity patterns of primary octavolateralis afferents might be found within the clupeid family of fishes in which the otic and lateralis systems are in close association (Greenwood. '73; Allen et al., '76; Denton and Blaxter, '76; Denton et al., '79).

A related group of questions pertain to the central organization of first-order auditory and vestibular input. Among the actinopterygians, auditory function is generally believed to reside in the sacculus and lagena (e.g., Fay and Popper, ' 80 ), and Bell ('81) has described relatively discrete central projections for the sacculus compared to those of the lagena and vestibular endorgans in mormyrids. However, as already mentioned, in some fish other end- organs are believed to function as the major auditory receptors, such as the utriculus of clupeids and the macula neglecta of chondrichthyans. Is the first-order projection of a given otic endorgan similar in all cases, regardless of the function of that endorgan? Or, alternatively: Are there specific vestibular and auditory nuclei in all fish, regardless of the variability of endorgan function? There is no information regarding either of these possibilities.

Finally, it is important to note that the range of variability in the morphology of the octavolateralis area has almost certainly not yet been sampled. Since the actinopterygians alone number over 20,000 species, forming the largest vertebrate group, it can be anticipated that additional classes of peripheral and central specializations of the octavolateralis system will be found as more species are investigated.

\section{ACKNOWLEDGMENTS}

I gratefully acknowledge the generous support of Dr. R. Glenn Northcutt as my mentor throughout my graduate training, during which I compiled the greater part of the data presented in this study. I also thank Dr. Mark R. Braford, Jr. for our many discussions of the ideas presented here, as well as for his assistance throughout the course of this study. Figure 1 was constructed with photographic negatives generously supplied by Dr. Rudolf Nieuwenhuys, and Figure 2 with negatives from Dr. R. Glenn Northcutt and Dr. Rudolf Nieuwenhuys. Thanks are also due to Dr. Sheryl Coombs, Dr. Donald Newman, Dr. Arthur N. Popper, and Dr. William Saidel for their assistance with various aspects of the manuscript. This report is partially based on the author's doctoral dissertation at The University of Michigan. It was supported in part by NIH grant 2 ROI NS 11006 to Dr. R.G. Northcutt and a Rackham Dissertation Grant from The University of Michigan to the author.

\section{ITERATURE CITED}

Allen, J.M., J.H.S. Blaxter, and E.J, Denton 11976) The functional anatomy and development of the swimbladder. inner ear-lateral line systern in herring and sprat. J. Mar. Biol. Assoc. U.K. 56:471-486.

Andrianov, G.N., and O.B. Ilyinsky (1973) Some func. tional properties of central neurons connected with the lateral-line organs of the catfish (Ictalurus nebulosus). J. Comp. Physiol. 86:365-376.

Bell, C.C. 11981) Central distribution of octavolatera] af. ferents and efferents in a teleost (Mormyridae). J. Comp. Neurol. 195:391-414. 
Beli, C.C., and C.J. Russell (1978) Termination of electroreceptor and mechanical lateral line afferents in the mortryrid acousticolateral area. J. Comp. Neurol. 182:367382.

Blaxter, J.H.S., E.J. Denton, and J.A.B. Gray (1\$81) Acoustico-lateralis system in clupeid fishes. In W.N 'Tavolga, A.N', Popper, and R.R. Fay tedst: Hearing and Sound Communication in Fishes. New York: SpringerVerJag, pp. 39-59.

Hodznick, D. and R.G. Northeute $\{1980 \uparrow$ Segregation of electro- and mechanoreceptive inputs to the elasno. branch medulla. Brain Res. 195:313-321.

Bodznick, D., and R.G. Northcutt (1981) Electroreception in lampreys: Evidence that the earliest vertebrates were electroreceptive. Science, 212:465-467.

Board, R.L., and C.B.G. Campletl (1977) Structural and functional organization of the lateral line system of sharks. Am. Zool. 17:431-441.

Boord, R.L.. and B.L. lRoberts (1980) Medullary and cere bellar projections of the statoacoustic nerve of the dogfish, Scyliorhinus canicula. J. Comp. Neurol. 193:57-68.

Bullock, T.H. (1974) An essav on the discovery of sen. sory recepurs and the assigninent of their functions toyether with an introduction to electroreceptors. In $A$. Fessard [ed]: Handbook of Sensory Physiology, Vol. III/3. New York: Springer.Verlag. pp. 1-12.

Bullock, 'T.H, S. Hagiwara, K. Kusano, and K. Negishi (1961) Evidenve for a category of electroreceptors in the lateral line of gymnotid fishes. Science 134:1426-1427.

Cahn. 1'.H. (1972) Sensory factors in the side-to-side spacing and positional orientation of the tura, Euthynnus affinis, during schooling. Fish. Bull, 74:471-502.

Caird, D.M. (1978) A simple cerebellar system: the lateral line Jobe of the goldfish. J. Comp. Physiol. $127: 61-74$

Corwin. J.T, (1977) Morphology of the macula neglecta in sharks of the genus Carcharhinas. J. Morphol. 152:341362.

Corwin, J.T. (1978) The relation of inner ear structure to the feeding behavior in sharks and rays. In $O$. Johari (ed): Scanning Ellectron Micruscopy, $\$$ F.M. Ine, Chicago, pp. 1105-1112.

Denton, F.J., and J.H.S. Biaxter [1976] The mechanical relationships between the clupeid swimbladder, inner ear, and lateral line. J. Mar. Biol. Assoc. U.K. 56:787-807.

Denton, F.J., J.A.B. (iray, and J.H.S. Blaxter \{1979\} The mechanics of the clupeid acoustico-lateralis system: Frequency responses. J. Mar. Biol. Assoc. U,K. 59:27-47.

Dijkgraaf, S. \{1963\} The functioning and significance of the lateral line organs. Biol. Rev. 36:51-105.

Dijkgraaf, S. (1967) Biological significance of the lateral Jine organs. In P.H. Cahn, ted): Lateral Line Detectors. Bloomington: lndiana University Press, pp. 83-95.

Fay, R.R.J.l Kendall, A.N. Popper, and A.L. Tester 119741 Vibration detection by the macula neglecta of sharks. Comp. Biochem. Physiol. 47A:1235-1240.

Fay, RR., and A.N. Popper 11980) Structure and function in teleost auditory systems. In A.N. Popper and R.R. Fay ieds): Comparative Studies of Hearing in Vertebrates. New York: Springer-Verlag; pp. 3-42.

Gardiner, B.G, $\{1973\}$ Interrelationships of tuleostomes In P.JI. Greenwond. R.S. Miles, and C. Palterson (eds): In terrelationships of Fishes. New York: Academic Press, pp. $105-135$.

Greenwood, P.H. \{1973\} lnterrelationships of osteoglossomorphs. In P.H. Greenwood, R.S. Miles, and C. Patlerson (eds): Interrelationships of Fishes. New York: Academic Press, pp. 307-332.

Johnston. J.B. (190]) The brain of Acipenser. Zool. Jalir. Anat. Ontog. 15:59-260.

Johnston, J.B. (1902) The brain of Petromyzon. J. Comp. Neurol. 12:1-86.
Jorgenson, J.M., A. Flock, and IJ. Wersal! (1972) The I orenzian ampullae of Polyocton spatula. 7. Zellforsch. 130: $362-377$.

Kleerekoper, H., and K. Sibakin (1956a) Spike potentials produced by the sea lamprey (Petromyzon marinus) in the water surrounding the head regrion. Nature 178:490-491.

Kleerekoper, H., and K. Sibakin $\$ 1956 \mathrm{~b})$ An investigation of the electrical "spike" potentials produced by the sea lamprey (Petromyzon marinus) in the water surrounding the head region. J. Fish, Res, Bd. Can, $13: 375-383$.

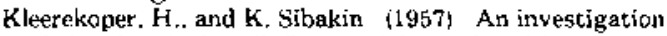
of the electrical "spike" potentials produced by the sea lamprey (Petromyzon mannus) in the waler surrounding the head region. II. J. Fish. Kes. Bd. Can. 14:145-151.

Larseli, $0.11967 \mid$ The Comparative Anatomy and Histol. ogy of the Cerebellum from Myxinoids through Birds. J Jansen (ed): Minmeapolis: University of Minnesota Press.

Liem K.F., and G.V. Lauder (in press) The evolution and interrelationships of the actinopterygian fishes. In R.G. Northcutt and R.E. Davis (eds): Fish Neurobiology, Vol. l. Ann Arbor: University of Michigan Press.

Lissman, H.W, and K.E. Machin (1958) 'The mechanism of object location in Gymnarchis.s niloticus and similar fish. J, Nxp. Biol. 35:451-486.

Lowenstein, 0. (1971) The labyrinth. In W.S. Hoar and D.S. Randall fedst: Physiology of Fishes. New York: Academic Press. pp. 207-240.

Lowenstein, O., and R.A. Thornhill (1970) The labyrinth of Myxine: Anatomy, ultrastructure, and electrophysiol. ogy. Proc. R. Soc. Lond. B., 176:21-42.

Luilen, P.G.M. 11975\} The central projections of the Lrigeminal, facial, and anterior lateral line nerve in the carp ICyprinus carpio L.). J. Comp. Neurol. $t 60: 399-418$.

Maler, I. (1973) The posterior lateral line lobe of a mor. myrid fish-- A Golgi study. J. Comp. Neurol, 1,52:281-298.

Maler, L. \{1974\} The acousticolateral area in bony fish and its cerebellar relations. Brain Behav. Evol. $10.130-145$

Mater, I. (1979) The pusterior lateral line lobe of certain kymnotid fish: Quantitative light microscopy. J. Comp. Neurol. 183:323-364.

Maler, L., H.J. Karlen, and M.V.L. Bennett (1973a) The centrai connections of the posterior lateral line nerve of Gnathonemus petersi. J. Comp. Neurol, 151:57-66.

Maler, L., H.J. Karten, and M.V.L. Bennett 11973b) The central connections of the anterior lateral bine nerve of Gnathonemus petersi. J. Comp. Neurol, 151:67-84.

Maler, I.. T. Finger, and H.J. Karten 11974) Differential projections of ordinary lateral line receptors and electro. receptors in the gymnotid fish, Apteronotus (Sternarchus) albifrons. J. Comp. Neurol, 15k:363-382.

McCormick, C.A. (1978) Central Projections of the Later alis and Eighth Nerves in the Bowfin, Amia calva. Doc. toral Dissertation, The University of Michigan.

McCormick, C.A. \{1981) Central projections of the lateral line and eighth nerves in the bow fin, Amia calva. 3 , Comp. Neurol.. 197:1-15.

McCready, P.J., and R.L. Boord (1976) The topography of the superficial roots and ganglia of the anterior later al line nerve of the smonth dogfish. Mustetes canis. J. Mor. phol. 150:527-538.

McCreery, D.R, (1977) Two types of electroreceptive Jaler demniscal neurons of the Jateral line Jobe of the catfish Ictalurus nebulosis: Connections from the lateral line nerve and steady-state frequency response characterislics. J. Comp. Physiol, 113:317-339.

Nieuwenhuys, R. \{1974\} Topological analysis of the brain stem: A general introduction. J. Comp. Neurol. 1.56:255-276.

Northcutt. R.G. (1979a) Central projections of the eighth cranial nerve in lampreys. Br. Mes. 167:163-167.

Northcutt, R.G. 11979b) Primary priertions of eighth 
nerve afferents in a teleost, Gillichthys mirabilis. Anat. Kec. 193:638.

Northcutt, R.G. (1980) Central auditory pathways in anamniotic vertebrates. In A.N. Popper and R.R. Fay (eds): Comparative Studies of Hearing in Vertebrates. New York: Springer-Verlag: pp. 79-118.

Northcutt, R.G., D.A. Bodznick, and 'T.H. Bullock $\{1980\}$ Most non-teleast fishes have electroreception. Proc's. Inl'l. Union Physiological Sciences XIV:614.

OConnell, C.P. (1955) The gas bladder and its relation to the inner ear in Sardinops caerulea and Engraulis mordar. Fish. Bull. 56:505-533.

Partridge. B.L., and T.J. Pitcher (1980) The sensory basis of fish schools: Relative roles of later al line and vision. J. Comp. Physiol. A. 135:315-325.

Pearson, A.A. (1936a) The acustico-lateral nervous sys. tern in fishes. J. Comp. Neurol. 64:235-273,

Pearson, A.A. $\{1936 \mathrm{~b}\}$ The acustico-lateral centers and the cerebellum, with fiber connections, of fishes. J. Comp. Neurol. 65:201-294.

Pfeiffer. W. 11968) Die fahrenholzchen Organe der Dipnoi und Brachiopterygii. Z. Zelliorsch. 90:127-147.

Pitcher. 'T.J., B.L. Partridge, and C.S. Wardle $(1976)$ A blind fish can school. Science 194:963-965.

Popper, A.N., and R.R. Fay (1977) Structure and func tion of the elasmobranch auditory system. Am. Tonl. 17:443-452

Popper, A.N., and C. Platt 11979) The herring ear has a unique receptor pattern. Nature 20:832-839.

Réthelyi, M., and T. Szabo (1973) Neurohislological analyses of the lateral lobe in a weakly electric fish, Gymnot us carapo (Gymnotidae, Pisces). Exp. Br. Res. 18:323-339

Retzius, B. \{1881\} Das Gehororgan der Wirbelthiere, Vol. 1. Stockholm: Samson and Wallin.

Romer, A.S. (1966) Vertebrate Paleontology, 3rd Ed. Chicago: University of Chicago Press.

Russell, I.J. (1976) Central inhibition of lateral line input in the medulta of the goldfish by neurones which control active bodv movement. J. Comp. Phvsiol. IJI. 335-358.

Sand, 0. (1981\} The lateral-line and sound reception. in W.N. Tavolga, A.N. Popper, and R.K. Fay (eds): Hearing and Sound Communication in Fishes. New York: Springer-Verlag, pp. 459-480.

Schaeffer, B. (1973) Interrelationships of chondrosteans. In P.H. Greenwood, R.S. Miles, and C. Patter son (eds): 1nterrelationships of Fishes. New York: Academic Press, pp. 207-226.

Schwart2, E. (1967) Analysis of surface-wave perception in some teleosts. In P.H. Cahn (ed): Lateral Line De teclors. Bloornington: Indiana University Press, pp. 123-134.

Stipetic. E. (1939) Uber das Gehororgan der Mormy. riden. 7eit. Vergl. Physiol. 26:740-752.

Szabo, 'T., S. I Jbouban, and F. Haugede-Carre (1979) Convergence of common and specific sensory afferents to the cerebellar auricle (auricula cerebelli) in the teleost fish Gnathonemus demonstrated by HRP method. Brain Res. t68:619-622.

Szabo, T., M. Ravaille, and S. ljbouban (1978) Club endings of primary atferent fibers identified by anterograde horseradish peroxidase labelling. An EM study. Neurosci. Lett. $9: 7-15$

Teeter. J.H., and M.V.L. Bennett (1976) Ampullary elec troreceptors in sturgeon. Neurosci. Abstr. 2:185.

Tester. A.L.. J.I. Kendall, and W.B. Milisen 11972) Morphology of the ear of the shark genus Carcharhinus with particular reference to the macula negkecta. Pacific Sci. 26:264-274.

Thompson. K.S. (1977) On the individual history of cos mine and a possible electrorectptive function of the porecanal system in fossil fishes. In S.M. Andrews, R.S. Miles, and A.D. Walker leds): Problems in Vertebrate Evolution. New York: Academic Press. pp. 247-271.

van Bergeijk. W.A. 11967\} The evolution of vertebrate hearing. In W.D. Neff ledi: Contributions to Sensory Physiolosy, Vol. 2. New York: Academic Press. pp. 1-49. van der Horst, C.J. (1925) The cerebellum of fishes. I. General morphology of the cerebellum. Proc. H. Acad. Amslerdam 28:735-746.

Wiley, E.O. 11979y Ventral gill arch muscles and the in. terrelationships of gnathostomes, with a new classification of the Vertebrata. 7ool. J. Linn. Soc. 67;149-179. 